\title{
Intercropping of Pea and Spring Cereals for Weed Control in an Organic Farming System
}

\author{
Lina Šarūnaitè ${ }^{1}$, Aušra Arlauskienè ${ }^{2}$ Irena Deveikytè1, \\ Stanislava Maikštènienè ${ }^{2}$ and Žydrè Kadžiulienè ${ }^{1}$ \\ 1 Institute of Agriculture, Lithuanian Research Centre for Agriculture and Forestry,

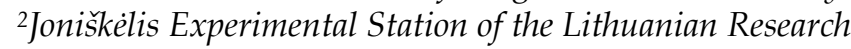 \\ Centre for Agriculture and Forestry, \\ Lithuania
}

\section{Introduction}

Organic or sustainable management systems is focused on the creation of greater crop spatial and temporal diversification in crop rotation, and a reduction in the negative effects for food quality and environment, specifically a reduction in synthetic pesticide use (Lazauskas, 1990; Anderson, 2010). The relationship and competition beetween crop and weed populations is determined by the practical application of basic ecological principles in such management systems (Liebman \& Davis, 2000; Singh et al., 2007). Crop diversification, which alters the composition of weed communities and influences their density, helps stabilize agricultural crop and weed communities (Barbery, 2002). Different seasonal types of agricultural crops (e.g. winter or spring crops) with different growth cycles and agronomic requirements provide unfavourable conditions for segetal plant life cycles. This prevents weed spread, germination, growth and seed ripening (Liebman \& Dyck, 1993; Koocheki et al., 2009). In organic farming systems, an important role is assigned to a crop rotation (plant sequence diversification), catch crops and intercrops (Liebman \& Davis, 2009; Anderson, 2010), and crop potential usage for suppressing and tolerating segetal plants (Liebman \& Dyck, 1993).

Intercropping is the simultaneous production of more than one crop species in the same field (Willey \& Rao, 1980). Intercrops can be combinations of two or more species, including both annuals and perennials or a mixture (Anil et al., 1998). When two or more crops are growing together, each must have adequate space to maximize synergism and minimize intercrop competition and decrease weed competition. Therefore, before implementing specific intercropping systems, it should be taken into account: spatial arrangement (Malezieux et al., 2009); plant density (Neumann et al., 2007; Andersen et al., 2007); maturity dates of the crops being grown (Anil et al., 1998); and plant architecture (Brisson et al., 2004).

One of the most commonly used intercropping mixtures is the legume/nonlegume (usually cereals) combination (Ofori \& Stern, 1987; Anil et al., 1998; Hauggaard-Nilsen et al., 2008). Biologically fixed nitrogen $\left(\mathrm{N}_{2}\right)$ of legumes is the most common plant growth stimulating factor and improved crop competition with respect to weed species in organic or sustainable farming systems (Berry et al., 2002). Studies in the literature have demonstrated that grain legumes are weak suppressors of weeds, but mixing species in a cropping system becomes a 
way to improve the ability of the crop itself to suppress weeds (Lemerle et al., 2001; Mohler, 2001; Jensen et al., 2006). Therefore, intercropping of cereals and grain legumes: pea (Pisum sativum L. (Partim), lupin (Lupinus angustifolius L.), bean (Vicia faba L.), vetch (Vicia sativa L.) et ctr is a neglected theme in agricultural research. Weeds continue to play a major limiting role in agricultural production. The control of weeds using classical pesticides raises serious concerns about food safety and environmental quality, which have dictated the need for alternative weed management techniques.

The field experiments were carried out in 2007-2010 at the Institute of Agriculture (Dotnuva, loamy soil) and the Joniskelis Experimental Station (Joniskelis, clay loam soil,) of the Lithuanian Research Centre for Agriculture and Forestry. The aim of this study was to determine the effect of intercropping pea with spring cereals on crop competition, yield performance and weed control in organic farming conditions. The following trial design was used for intercrops and sole crops: 1) pea (cv. 'Pinochio'), Ps, 2) pea/spring wheat (Triticum aestivum L. emend. Fiori et Paol., cv. 'Estrad'), PWi, 3) pea/spring barley (Hordeum vulgare L., cv. 'Aura'), PBi, 4) pea/oats (Avena sativa L., cv. 'Migla'), POi, 5) pea/spring triticale ( $\times$ Triticosecale Wittm., cv. 'Nilex'), PTi, 6) spring wheat, Ws, 7) sprig barley, Bs, 8) oats, Os, 9) spring triticale, Ts. The experimental plots were laid out in a complete one-factor randomised block design in three replicates. Individual plot size was $2.5 \times 12 \mathrm{~m}$. The intercrop design was based on the proportional replacement principle, with mixed pea grain and spring cereals grain at the same depth in the same rows at relative frequencies (50:50 -a relative proportion of grain legume and spring cereals seeds). Wheat seeds rate were 5.5, barley 4.7, oat 6.0, triticale 4.5 and pea 1.0 mln seeds ha- ${ }^{-1}$ for sole crop. Weeds were assessed twice: at stem elongation growth stage (BBCH 32-36) and at development of grain filling growth stage (BBCH 73). Mass of weeds and botanical composition was determined in $0.25 \mathrm{~m}^{2}$ at 4 settled places of each treatment. The experimental data were processed by the analysis of variance and correlationregression analysis methods using a software package "Selekcija". Weed number and mass data were transformed to $\sqrt{x+1}$.

\section{Benefits of intercropping of cereal and grain legume}

\subsection{Yield and quality of intercrops}

Cereal and legume intercropping systems are one of the important agronomic practices, wherein usually the productivity of the system as a whole is higher in comparison with that of their performance individually. Intercropping of cereals with grain legumes has been a common cropping system in rain-fed areas and especially in the Mediterranean countries (Anil et al., 1998; Lithourgidis et al., 2006). Grain legumes extensively used in intercropping with cereal include pea, vetch, lupin and bean (Hauggaard-Nielsen et al., 2001; Andersen et al., 2005; Ghaley et al., 2005; Berk et al., 2008). A number of different cereal crops have been proposed to be appropriate for intercropping with grain legumes such as barley oat, triticale, and wheat (Thomson et al., 1992; Berk et al., 2008). Intercropping advantages include improved soil conservation (Anil et al., 1998), yield stability (Hauggaard-Nielsen et al., 2003; Lithourgidis et al., 2006) and favours weed control (Banik et al., 2006). This leads to improved utilisation of environmental resources, light, water, and nutrients, in a multiple plant species community (Brisson et al., 2004; Corre-Hellou et al., 2007). The legume can provide $\mathrm{N}$ benefits to the nonlegume directly through mycorrizal links, root exudates, or decay of roots and nodules; or indirectly through a spring effect, where the legume fixes 
atmospheric dinitrogen $\left(\mathrm{N}_{2}\right)$, and thereby reducing competition for soil $\mathrm{NO}_{3}{ }^{-}$with the nonlegume (Anil et al., 1998). In intercropping the risk of nitrogen losses through leaching is substantially reduced in comparison to sole cropped pea (Neumann et al., 2007). Urbatzka et al. (2009) suggest, when pea is cultivated in a mixture with cereals, the $\mathrm{N}$ utilization effect was higher than in sole pea crop. In Danish and German experiments, the accumulation of phosphorous $(\mathrm{P})$, potassium $(\mathrm{K})$ and sulphur $(\mathrm{S})$ was $20 \%$ higher in the intercrop (50:50) than in the respective sole crops (Hauggaard-Nielsen et al., 2009). The concentration of nitrogen is one of the most important criteria for grain quality evaluation. Pea intercropped with spring cereal increased the nitrogen concentration in intercrops compared with sole cereal (Ghaley et. al., 2005; Mariotti et al., 2006). Thus, better nutrition conditions are created in intercrops, therefore crops have a higher competitive ability against weeds.

Results from our study conducted in Dotnuva suggests that intercrops were less productive than sole pea crop (except for pea intercropped with wheat). However, the pea / barley and pea/triticale intercrops were slightly more productive than the sole cereal crops (Table 1). At Dotnuva, according to productivity, the dual-component intercrops were ranked in the following order: pea / wheat > pea / triticale; pea / barley > pea / oats. The data from the Joniskelis site show that in a heavy loam Cambisol, crop productivity was on average $20.5 \%$ higher, compared with that of crops grown in the Dotnuva site (Table 1).

\begin{tabular}{|c|c|c|c|c|c|c|c|}
\hline \multirow{3}{*}{$\begin{array}{l}\text { Sole crops and } \\
\text { intercrop }\end{array}$} & \multirow{3}{*}{$\begin{array}{c}\text { Crop } \\
\text { component }\end{array}$} & \multicolumn{3}{|c|}{ Loamy soil (Dotnuva) } & \multicolumn{3}{|c|}{ Clay loam soil (Joniskelis) } \\
\hline & & \multirow{2}{*}{$\begin{array}{c}\text { Grain } \\
\text { yield } \\
\left(\mathrm{kg} \mathrm{ha}^{-1}\right)\end{array}$} & \multicolumn{2}{|c|}{ Nitrogen } & \multirow{2}{*}{$\begin{array}{c}\text { Grain } \\
\text { yield } \\
\left(\mathrm{kg} \mathrm{ha}^{-1}\right)\end{array}$} & \multicolumn{2}{|c|}{ Nitrogen } \\
\hline & & & $\mathrm{mg} \mathrm{kg}^{-1}$ & $\mathrm{~kg} \mathrm{ha}^{-1}$ & & $\mathrm{mg} \mathrm{kg}^{-1}$ & $\mathrm{~kg} \mathrm{ha}^{-1}$ \\
\hline Ps & pea & 2936.5 & 37.2 & 108.8 & 2896.6 & 33.6 & 83.8 \\
\hline \multirow[t]{3}{*}{$\mathrm{P}+\mathrm{SWi}$} & pea & 550.4 & 37.3 & 20.5 & 795.3 & 34.5 & 23.5 \\
\hline & wheat & 2401.3 & 22.2 & 54.8 & 2473.2 & 20.0 & 42.3 \\
\hline & total & 2951.9 & 24.9 & 75.3 & 3268.5 & 23.5 & 65.7 \\
\hline \multirow[t]{3}{*}{$\mathrm{P}+\mathrm{SBi}$} & pea & 565.7 & 36.9 & 20.6 & 649.0 & 33.1 & 18.2 \\
\hline & barley & 2184.5 & 19.6 & 44.9 & 2386.4 & 18.7 & 38.4 \\
\hline & total & 2750.1 & 24.2 & 65.5 & 3035.4 & 21.8 & 56.6 \\
\hline \multirow[t]{3}{*}{$\mathrm{P}+\mathrm{Oi}$} & pea & 445.2 & 37.0 & 16.6 & 432.9 & 33.3 & 12.2 \\
\hline & oat & 2109.9 & 18.5 & 39.3 & 3837.5 & 17.4 & 57.1 \\
\hline & total & 2555.4 & 22.4 & 55.9 & 4270.4 & 19.0 & 69.4 \\
\hline \multirow[t]{3}{*}{$\mathrm{P}+\mathrm{STi}$} & pea & 520.7 & 34.2 & 19.2 & 1240.8 & 33.4 & 35.5 \\
\hline & triticale & 2214.6 & 26.6 & 48.9 & 2000.6 & 23.4 & 39.3 \\
\hline & total & 2735.3 & 23.3 & 68.2 & 3241.4 & 27.2 & 74.8 \\
\hline SWs & wheat & 3002.9 & 19.2 & 59.8 & 3387.9 & 18.7 & 53.9 \\
\hline SBs & barley & 2583.3 & 16.6 & 46.4 & 2995.8 & 17.7 & 45.4 \\
\hline Os & oat & 2897.0 & 17.6 & 48.3 & 3955.1 & 16.6 & 56.0 \\
\hline STs & triticale & 2717.9 & 19.5 & 55.1 & 3220.5 & 21.7 & 59.9 \\
\hline \multicolumn{2}{|c|}{$\mathrm{LSD}_{05}$} & 743.12 & 5.70 & 20.06 & 611.8 & 6.32 & 9.42 \\
\hline
\end{tabular}

Note. Sole crop: Ps -pea, SWs - spring wheat, SBs - spring barley, Os -oat, STs - spring triticale; intercrop: $\mathrm{P}+\mathrm{SWi}$ - pea and spring wheat, $\mathrm{P}+\mathrm{SBi}$ - pea and spring barley; $\mathrm{P}+\mathrm{Oi}$ - pea and oat, $\mathrm{P}+\mathrm{STi}$ pea and triticale.

Table 1. Grain yield and nitrogen content of pea and spring cereals grown as sole crops and in dual-component intercrops data averaged over 2007-2010 
Clay loam soils have high capillary water capacity, therefore plants are not so readily affected by lack of soil moisture (Maikštėnienè et al., 2006). The data from the Joniskelis site evidenced that all intercrops were more productive than sole pea crop. Moreover, the sole spring cereal was lower yielding than cereal intercropped with pea (except for pea intercropped with wheat). The rough structure of these soils was more favourable for cereals than for peas. At Joniskelis, according to productivity, intercrops were ranked in the following order: pea / oats > pea / wheat, pea / triticale > pea / barley. In dual-component intercrops with increasing productive density of cereals and their share in the yield, the total yield of the intercrops increased in Dotnuva $(\mathrm{r}=0.650 ; P<0.05 ; \mathrm{r}=0.969 ; P<0.01$, respectively) and in Joniskelis $(r=0.576 ; P<0.05 ; \mathrm{r}=0.916 ; P<0.01$, respectively). Results obtained in various soils showed that when peas were grown mixed with oats or barley, their productivity was directly influenced only by cereals yield $(\mathrm{r}=0.991 ; P<0.01 ; \mathrm{r}=0.971$; $P<0.01$, respectively), whereas the productivity of peas grown in mixed crop with wheat or triticale was influenced by both components: yields of cereals $(\mathrm{r}=0.825 ; P<0.01$ and $\mathrm{r}=$ 0.984; $P<0.01$, respectively) and pea $(\mathrm{r}=0.637 ; P<0.05$ and $\mathrm{r}=0.842 ; P<0.01$, respectively) of the intercrop.

The accumulation of nitrogen in cereal grain is an indicator of different crop species competitive power. The findings from Dotnuva site showed that pea grown in sole crop accumulated $2.2 \%$ more nitrogen than pea intercropped with cereal. However, the grain nitrogen concentration of cereal intercropped with pea averaged 19.2\% higher than that in sole cereal crop. The nitrogen concentration in pea grain was slightly lower in Joniskelis compared with Dotnuva. The amount of grain nitrogen did not differ between sole pea crops and pea intercrops. The grain nitrogen concentration of cereal intercropped with pea averaged $6.4 \%$ higher than that in sole crop. At both experimental sites, the highest grain nitrogen concentration was in spring wheat and triticale intercropped with pea.

In loamy soil (Dotnuva), sole pea produced a higher yield, therefore the nitrogen content was $29.8 \%$ higher compared to the corresponding data in clay loam soil (Joniskelis). The intercrops accumulated similar nitrogen concentrations in the total grain yield in both experimental sites. The amount of nitrogen in total grain yield of intercrops was greater by $26.3 \%$ in Dotnuva and by $23.8 \%$ in Joniskelis compared to the averaged amount of nitrogen in grain of sole cereal crop in corresponding experimental sites.

\subsection{Intercropping for weed management}

Weed management is a key issue in organic farming system (Bond \& Grundy, 2001). Improvement of crop competition with weeds has been emphasised as the benefit of the increased sowing density of sole crops or intercropping (Auskalniene \& Auskalnis, 2008; Liebman \& Davis, 2000). Individual cereal species vary in their competitiveness against weeds. Weed suppression has been found to be greater in intercrops compared with sole crops, indicating synergism among crops within intercrops (Liebman \& Dyck, 1993; Bulson et al., 1997; Szumigalski \& van Acker, 2005; Deveikytè et al., 2008, 2009). In an organic farming weeds are controlled not only by direct means (manually or mechanacilly) and preventive measures (appropriate crop rotation, tillage, crop management) but also by increasing crop tolerance of weeds (choice of genotypes, sowing method, fertilization strategy) (Barbery, 2002; Anderson, 2010). 


\subsubsection{Weed species composition, germination time and conditions}

According to literature, annual weeds, whose short vegetation period coincides with the cereal growth season, are most common in spring cereals (Rassmusen, 2002; Barbery, 2002). Weed seed germination is influenced by many factors such as field history and seed bank, soil properties, tillage practices and crop technologies. Annual weed seeds germinate at different times. Thlaspi arvense L. germinated at the earliest time, other weeds germinated when soil temperature had warmed up. Fallopia convolvulus (L.) A. Löve germinated a little later (Špokienè, 1995). In general, the intensive weed germination period is when soil warms up to $10-15^{\circ} \mathrm{C}$. Therefore, the most intensive competitive interaction between weeds and crops occurs in the second half of May until mid June and late July to mid August in Eastern Europe (Špokienè, 1995).

Our results revealed that annuals dominated the weed flora composition (7-18 species) while there were fewer perennials (2-8 weed species). The most common annual weed species on fertile soils were: Chenopodium album L., Veronica arvensis L., Stellaria media (L.) Vill., Galium aparine L., Fallopia convolvulus, Thlaspi arvense, Viola arvensis Murray , Lamium purpureum L., Polygonum aviculare L., Polygonum persicaria L., Fumaria officinalis L., Tripleurospermum perforatum (Merat) M. Lainz. The dominance of these weed species can be explained by a very good adaptation to the existing soil and climatic conditions and soil tillage regime (Protasov, 1995). Such species are characterized by higher soil nutrient assimilation compared to agricultural crop plants. The following perennial weed species were identified: Cirsium arvense (L.) Scop., Sonchus arvensis L., Taraxacum officinale F.H. Wigg., Equisetum arvense L., Tussilago farfara L. Both experimental sites were similar in weed species and number (Table 2).

In a loamy soil (Dotnuva), plant diversity in crop rotation was higher (at cereal stem elongation growth stage $\mathrm{BBCH} 32-36$ ) Chenopodium album was the dominant weed species from the 12-13 species identified. This species accounted for $61.7-77.2 \%$ of the total weeds documented. Whereas, in clay loam soil (Joniskelis), there were fewer (7-9) weed species of which the most frequent were Stellaria media (16.1-26.9\%), Veronica arvensis (9.8-16.8 \%), Galium aparine (7.6-13.3\%), Chenopodium album (7.3-12.9 \%), and Fallopia convolvulus (6.9-9.9 $\%)$. Based on Špokienè and Povilionienè's (2003) findings, according to weed harmfulness reduction, the species can be ranked as follows: Cirsium arvense (10) > Sonchus arvensis (9) > Taraxacum officinale (8) > Chenopodium album, Stellaria media (7) > Galium aparine, Fallopia convolvulus (6)> Polygonum sp. (5)> Thlapsi arvense (4). According to Lithuanian researchers' data, weed species such as Viola arvensis, Veronica arvensis, and Lamium purpureum are less harmful; however, the number of weed species in a crop (weed harmfulness threshold) is of great importance (Špokienè \& Povilionienè, 2003).

Our research data (Joniskelis) revealed that weed germination was significantly lower in pea / barely intercrop, spring wheat and oat sole crops compared to the pea sole crop. At Dotnuva and Joniskelis experimental sites the weed number tended to decrease 3.6-19.5\% and 3.9-19.5 \%, respectively. In Joniskelis, all intercrops and sole crops had good suppression of Thlaspi arvense. Slightly fewer weeds germinated in cereal sole crops compared to intercrops. The germination of Galium aparine was significantly lower, and the number of Fallopia convolvulus tended to decrease in Joniskelis' cereal sole crop. Different crops (intercrop and sole crop) had little effect on the variation of perennial weed number. 
Further suppression of weeds depends on the crop's ability to impede weed growth. It is widely accepted that the competitive interaction between weeds and crops does not occur only at early stages of plant development (Lazauskas, 1990).

\begin{tabular}{|c|c|c|c|c|c|c|c|c|c|c|}
\hline \multirow{3}{*}{ Species } & \multirow{3}{*}{ Place } & \multicolumn{9}{|c|}{ Sole crops and intercrop (BBCH 32-36) } \\
\hline & & Ps & P+SWi & $\mathrm{P}+\mathrm{SBi}$ & $\mathrm{P}+\mathrm{Oi}$ & P+STi & SWs & SBs & Os & STs \\
\hline & & \multicolumn{9}{|c|}{ Weed $\mathrm{m}^{2}$} \\
\hline \multirow{2}{*}{$\begin{array}{c}\text { Viola } \\
\text { arvensis }\end{array}$} & Dotnuva & 2.3 & 1.7 & 1.9 & 2.3 & 1.9 & 2.6 & 2.2 & 1.6 & 1.7 \\
\hline & Joniskelis & 5.8 & 3.5 & 3.3 & $2.8^{*}$ & 5.2 & 3.5 & 4.7 & $2.5^{*}$ & 5.8 \\
\hline \multirow{2}{*}{$\begin{array}{l}\text { Veronica } \\
\text { arvensis }\end{array}$} & Dotnuva & 1.1 & 0.6 & 0.6 & 0.3 & 1.2 & 0.6 & 0.4 & 0.4 & 0.7 \\
\hline & Joniskelis & 8.7 & 8.8 & 7.7 & 5.5 & 10.0 & 8.7 & 10.0 & 6.8 & 7.3 \\
\hline \multirow{2}{*}{$\begin{array}{l}\text { Thlapsi } \\
\text { arvense }\end{array}$} & Dotnuva & 3.7 & 1.7 & 0.9 & 0.9 & 0.8 & 1.0 & $0.7^{*}$ & 1.6 & $0.4^{*}$ \\
\hline & Joniskelis & 8.0 & $3.8^{*}$ & $2.8^{* *}$ & 4.2 & 4.7 & $3.3^{* *}$ & $3.3^{*}$ & $2.5^{* *}$ & $3.3^{* *}$ \\
\hline \multirow{2}{*}{$\begin{array}{l}\text { Galium } \\
\text { aparine }\end{array}$} & Dotnuva & 0 & 0 & 0 & 0 & 0 & 0 & 0 & 0 & 0 \\
\hline & Joniskelis & 8.8 & 6.0 & $5.8^{*}$ & 7.0 & 6.7 & $5.0^{*}$ & $5.2^{*}$ & $4.0^{* *}$ & $4.8^{*}$ \\
\hline \multirow{2}{*}{$\begin{array}{c}\text { Fallopia } \\
\text { convolvulus }\end{array}$} & Dotnuva & 1.9 & 1.1 & 1.6 & 1.3 & 0.7 & 2.1 & 1.3 & 2.0 & 1.2 \\
\hline & Joniskelis & 5.3 & 4.2 & 4.7 & 5.5 & 6.3 & 3.5 & 3.0 & 3.8 & 5.5 \\
\hline \multirow{2}{*}{$\begin{array}{c}\text { Stellaria } \\
\text { media }\end{array}$} & Dotnuva & 2.7 & 1.9 & 2.2 & 3.2 & 2.3 & 2.4 & 2.4 & 1.8 & 2.2 \\
\hline & Joniskelis & 10.7 & 12.2 & 11.0 & 12.5 & 9.3 & 10.5 & 14.7 & 9.5 & 17.0 \\
\hline \multirow{2}{*}{$\begin{array}{c}\text { Chenopodium } \\
\text { album }\end{array}$} & Dotnuva & 35.7 & 35.6 & 35.7 & 33.8 & 36.6 & 32.8 & 37.2 & 41.9 & 35.7 \\
\hline & Joniskelis & 8.5 & 7.8 & 5.3 & 5.8 & $4.7^{*}$ & $4.2^{*}$ & 5.8 & $4.5^{*}$ & 4.8 \\
\hline \multirow{2}{*}{$\begin{array}{c}\text { Polygonum } \\
\text { persicaria }\end{array}$} & Dotnuva & 1.2 & 0.7 & 0.6 & 0.7 & $0.2^{* *}$ & $0.1^{* *}$ & $0.2^{* *}$ & 0.7 & $0.3^{* *}$ \\
\hline & Joniskelis & 0 & 0 & 0 & 0 & 0 & 0 & 0 & 0 & 0 \\
\hline \multirow{2}{*}{$\begin{array}{c}\text { Polygonum } \\
\text { aviculare }\end{array}$} & Dotnuva & 1.0 & 0.1 & 1.4 & 0.6 & 0.7 & 0.7 & 0.6 & 0.8 & 1.7 \\
\hline & Joniskelis & 0 & 0 & 0 & 0 & 0 & 0 & 0 & 0 & 0 \\
\hline \multirow{2}{*}{$\begin{array}{l}\text { Chaenorrhinum } \\
\text { minus }\end{array}$} & Dotnuva & 1.9 & 2.2 & 1.8 & 2.1 & 1.9 & 2.9 & 1.2 & 2.3 & 2.2 \\
\hline & Joniskelis & 0 & 0 & 0 & 0 & 0 & 0 & 0 & 0 & 0 \\
\hline \multirow{2}{*}{$\begin{array}{l}\text { Cirsium } \\
\text { arvense }\end{array}$} & Dotnuva & 2.9 & 0.8 & 3.6 & 3.0 & 2.3 & 0.2 & 0.5 & 0.1 & 3.2 \\
\hline & Joniskelis & 0.2 & $3.7^{*}$ & 1.3 & 2.7 & 3.0 & 2.5 & 1.7 & 0.5 & $4.2^{* *}$ \\
\hline \multirow{2}{*}{$\begin{array}{l}\text { Sonchus } \\
\text { arvensis }\end{array}$} & Dotnuva & 1.8 & 0.7 & 0.1 & 0.9 & 1.0 & 0.3 & 1.0 & 1.4 & 0.4 \\
\hline & Joniskelis & 0.7 & 0.3 & 0.5 & 1.5 & 2.2 & 0.7 & 0.3 & 0.5 & 0.3 \\
\hline \multirow{2}{*}{$\begin{array}{c}\text { Total } \\
\text { number of } \\
\text { weeds }\end{array}$} & Dotnuva & 57.9 & 48.1 & 51.7 & 51.3 & 50.9 & 46.6 & 48.2 & 55.8 & 51.0 \\
\hline & Joniskelis & 66.3 & 60.5 & $53.2^{*}$ & 55.9 & 63.7 & $51.7^{*}$ & 60.0 & $44.0^{* *}$ & 63.2 \\
\hline \multirow{2}{*}{$\begin{array}{c}\text { Number of } \\
\text { weeds } \\
\text { species }\end{array}$} & Dotnuva & 12 & 13 & 13 & 13 & 13 & 13 & 13 & 13 & 13 \\
\hline & Joniskelis & 8 & 8 & 7 & 8 & 9 & 8 & 8 & 8 & 7 \\
\hline
\end{tabular}

Note. *differences are statistically significant as compared to the control at $P<0.05$, **-at $P<0.01$

Sole crop: Ps -pea, SWs - spring wheat, SBs - spring barley, Os -oat, STs - spring triticale; intercrop: $\mathrm{P}+\mathrm{SWi}$ - pea and spring wheat, $\mathrm{P}+\mathrm{SBi}$ - pea and spring barley; $\mathrm{P}+\mathrm{Oi}$ - pea and oat, $\mathrm{P}+\mathrm{STi}$ - pea and triticale.

Table 2. Weed emergence and density of the most important species in sole crop and intercrop data averaged over 2007-2010 


\subsubsection{The competitive ability of pea intercropped with different spring cereal species}

Intercropping advantages may be influenced by both plant density and relative frequency of the intercrop components (Subkowicz \& Tendziagolska, 2005). The density of plants in intercrops varied between different experimental location, soil and cultivation conditions in our research. According to crop density data, pea plant accounted for $27.2 \%$ of barley intercrop and $29.7 \%$ of wheat intercrop at Dotnuva site. The greater density of pea was observed in intercrop with oat and triticale (35.2 and 34.7\%, respectively). In Joniskelis, the number of pea plants was lower (20.3-24.6\%) in intercrops, except for pea intercropped with triticale $(34.7 \%)$.

The highest productive density of pea in sole crop and intercrop was obtained in a loamy soil (Dotnuva) while a lower density was observed in clay loam soil (Joniskelis). Productive stem density of pea in crop structure was similar: $12.0-18.4 \%\left(40-58\right.$ stems per $\left.\mathrm{m}^{2}\right)$ in loamy soil, $10.2-20.4 \%$ (28-43 stems per $\mathrm{m}^{2}$ ) in clay loam soil (Table 3). The more stable productive densities of intercrop were obtained in a loam soil (286-346 stems per $\left.\mathrm{m}^{2}\right)$ compared to a clay loam soil (211-275 stems per $\left.\mathrm{m}^{2}\right)$. This crop density in intercrop structure on a clay loam soil was determined by the specific properties of the soil (high clay content) and weather conditions. The weather conditions are essential on the formation of intercrop productivity and weed germination. They influence the optimal plant density and create the basis for competition between the components during crop germination period. The comparison between the different intercrops showed that the highest productive density was in pea intercropped with spring wheat (346 stems per $\left.\mathrm{m}^{2}\right)$ and with barley $\left(332\right.$ stems per $\mathrm{m}^{2}$ ) in a loam soil, and peas with oats $\left(275\right.$ stems per $\left.\mathrm{m}^{2}\right)$ and with wheat $\left(268\right.$ stems per $\left.\mathrm{m}^{2}\right)$ in a clay loam soil.

\begin{tabular}{|c|c|c|c|c|c|c|c|c|c|c|c|c|}
\hline \multirow{3}{*}{ Place } & \multirow{2}{*}{$\begin{array}{c}\text { Crop } \\
\text { component }\end{array}$} & \multicolumn{8}{|c|}{ Sole crops and intercrop (BBCH 73) } \\
\cline { 3 - 13 } & & Ps & P+SWi & P+SBi & P+Oi & P+STi & SWs & SBs & Os & STs \\
\hline & pea & 109 & 48 & 40 & 58 & 48 & & & & \\
\hline \multirow{3}{*}{ Dotnuva } & cereal & & 298 & 292 & 258 & 238 & 478 & 398 & 442 & 368 \\
\cline { 2 - 13 } & total & & 346 & 332 & 316 & 286 & & & & \\
\hline \multirow{3}{*}{ Joniskelis } & pea & 81 & 34 & 37 & 28 & 43 & & & & \\
\cline { 2 - 13 } & cereal & & 235 & 195 & 247 & 168 & 355 & 307 & 343 & 334 \\
\cline { 2 - 12 } & total & & 268 & 231 & 275 & 211 & & & & \\
\hline
\end{tabular}

Note. Sole crop: Ps - pea, SWs - spring wheat, SBs - spring barley, Os -oat, STs - spring triticale; intercrop: $\mathrm{P}+\mathrm{SWi}$ - pea and spring wheat, $\mathrm{P}+\mathrm{SBi}$ - pea and spring barley; $\mathrm{P}+\mathrm{Oi}$ - pea and oat, $\mathrm{P}+\mathrm{STi}$ pea and triticale.

Table 3. The productive density of sole crop and intercrop data averaged over 2007-2010

According to the literature, cereal has a stronger ability for weed suppression than pea (Andersen et al., 2007). German researchers note that crowding coefficients for semi-leafless pea cultivars were smaller than for conventional leafed types, therefore plant height of pea appears to be more important than plant leaf type for weed suppression (Rauber et al., 2001). The clay loam soil (Joniskelis) was more favourable for cereal growth: pea plants were 
shorter $(13.2 \%)$, and cereals taller (2.6-4.9\%, except for spring barley) compared with respective crops in a loamy soil (Dotnuva) (Table 4). The pea plants were 22.1-29.9 \% shorter (Dotnuva) and $34.1-42.0 \%$ (Joniskelis) compared to oat, spring wheat and tricicale. The height of spring cereals ranked as follows: oat $>$ triticale $>$ wheat $>$ barley. According to the study, the height of pea plants declined by $20.1-24.7 \%$ in higher density intercrops (Dotnuva), and in lower density intercrops (Joniskelis) by $11.0-25.0 \%$ compared to pea sole crops. The height of intercropped cereals was not significantly different than cereal sole crops. Pea plants intercropped with oat, in some cases with barely and triticale were taller than those of sole crops.

\begin{tabular}{|c|c|c|c|c|c|c|c|c|c|c|}
\hline \multirow{3}{*}{ Place } & \multirow{3}{*}{$\begin{array}{c}\text { Crop } \\
\text { component }\end{array}$} & \multicolumn{9}{|c|}{ Sole crops and intercrop (BBCH 73) } \\
\hline & & Ps & $\mathrm{P}+\mathrm{SWi}$ & $\mathrm{P}+\mathrm{SBi}$ & $\mathrm{P}+\mathrm{Oi}$ & P+STi & SWs & SBs & Os & STs \\
\hline & & \multicolumn{9}{|c|}{ Height of crop $(\mathrm{cm})$} \\
\hline \multirow{3}{*}{ Dotnuva } & pea & 56.7 & 42.9 & 43.6 & 42.7 & 45.3 & & & & \\
\hline & cereal & & 70.5 & 54.7 & 82.5 & 80.9 & 72.8 & 57.8 & 80.9 & 79.4 \\
\hline & $\begin{array}{l}\text { weighted } \\
\text { average }\end{array}$ & & 66.5 & 53.6 & 75.1 & 74.8 & & & & \\
\hline \multirow{3}{*}{ Joniskelis } & pea & 49.2 & 36.9 & 38.2 & 39.7 & 43.8 & & & & \\
\hline & cereal & & 72.4 & 58.7 & 89.4 & 79.6 & 74.7 & 56.6 & 84.9 & 82.8 \\
\hline & $\begin{array}{l}\text { weighted } \\
\text { average }\end{array}$ & & 67.9 & 55.5 & 84.4 & 72.2 & & & & \\
\hline
\end{tabular}

Note. Sole crop: Ps - pea, SWs - spring wheat, SBs - spring barley, Os -oat, STs - spring triticale; intercrop: $\mathrm{P}+\mathrm{SWi}$ - pea and spring wheat, $\mathrm{P}+\mathrm{SBi}$ - pea and spring barley; $\mathrm{P}+\mathrm{Oi}$ - pea and oat, $\mathrm{P}+\mathrm{STi}$ pea and triticale.

Table 4. The plant height in sole crop and intercrop data averaged over 2007-2010

The weed suppression depended on the growth intensity of the crop aboveground biomass during the growing season. The mass per pea plant and per cereal stem at the beginning of cereal heading (BBCH 51) showed that the intercrops produced more biomass (0.18-1.05 $\mathrm{g}$ ) compared to the cereal sole crops (Table 5). Comparison of different cereal species showed the lowest aboveground biomass per cereal stem was both in spring barley sole crop and intercropped with pea. Oat intercropped with pea accumulated the highest dry matter yield in the aboveground part. Here we identified the lowest aboveground mass per pea plant. The data of the aboveground mass suggested that pea grew slowly in intercrops until start of heading of cereals and poorly competed with cereals. During the experimental period, the aboveground mass was influenced by productive plant density but not by mass per stem. Peas produced more aboveground biomass in the second half of the vegetation period, in contrast to cereals, which already holds a dominant position in the first stages of growth. Weeds are suppressed for the durationof the vegetation period when the pea intercropped with cereal is established at appropriate densities. During the main crop growing period, when the development rate of the intercropped plant species do not coincide, favourable weather conditions for one or the other intercropped species can influence the degree of competition. The Joniskelis' experimental data indicated that the productive plant density in intercrops was lower for peas, which require higher nutrition area. 


\begin{tabular}{|c|c|c|c|c|c|c|c|c|c|c|}
\hline \multirow{2}{*}{ Indicators } & $\begin{array}{c}\text { Crop } \\
\text { component }\end{array}$ & \multicolumn{8}{|c|}{ Sole crops and intercrop (BBCH 51) } \\
\cline { 3 - 13 } & Ps & P+SWi & P+SBi & P+Oi & P+STi & SWs & SBs & Os & STs \\
\hline \multirow{2}{*}{$\begin{array}{c}\text { Dry } \\
\text { matter of } \\
\text { one stem } \\
(\mathrm{g})\end{array}$} & pea & 6.76 & 3.09 & 3.12 & 2.59 & 4.20 & & & & \\
\cline { 2 - 14 } & cereal & & 3.07 & 2.22 & 3.67 & 3.30 & 2.73 & 1.97 & 2.62 & 3.12 \\
\hline \multirow{2}{*}{$\begin{array}{c}\text { Dry } \\
\text { matter } \\
\left(\mathrm{g} \mathrm{m}^{-2}\right)\end{array}$} & average & & 3.08 & 2.41 & 3.59 & 3.55 & & & & \\
\cline { 2 - 13 } & pereal & 521.4 & 104.1 & 117.4 & 73.5 & 184.6 & & & & \\
\cline { 2 - 13 } & total & & 720.8 & 434.2 & 913.3 & 529.3 & 969.5 & 605.0 & 897.8 & 1010.9 \\
\hline
\end{tabular}

Note. Sole crop: Ps - pea, SWs - spring wheat, SBs - spring barley, Os -oat, STs - spring triticale; intercrop: $\mathrm{P}+\mathrm{SWi}$ - pea and spring wheat, $\mathrm{P}+\mathrm{SBi}$ - pea and spring barley; $\mathrm{P}+\mathrm{Oi}$ - pea and oat, $\mathrm{P}+\mathrm{STi}-$ pea and triticale.

Table 5. The aboveground mass of crop during vegetation period in sole crop and intercrop (BBCH 51), Joniskelis 2007-2010 averaged data

The pea was suppressed in intercrops, where the productive density of pea stems was $40-58$ (Dotnuva) and 28-43 stems $\mathrm{m}^{-2}$ (Joniskelis), the productive density of cereal was 238-298 and 168-247 stems $\mathrm{m}^{-2}$, respectively. This indicates that the mass per pea plant in intercrops was 1.6-2.6 times lower compared to pea sole crop. Therefore, at Joniskelis site, the aboveground mass of crops during the growing season (BBCH 51) was lower for pea / wheat by $14.9 \%$, pea/barley by $8.8 \%$, and pea/triticale by $29.4 \%$ compared to the respective cereal sole crop. Only oat grown in intercrop produced more dry matter $(9.9 \%)$ in aboveground mass compared to oat sole crop.

Indices allow researchers to quantify and express several attributes of plant competition, including competition intensity and importance, competitive effects and responses, and the outcome of competition (Weigelt \& Jolliffe, 2003). An aggresivity value of zero indicates that component crops are equally competitive. If aggressivity value is higher than zero the species in the crop dominates, if this value is lower than zero the species is being chocked (Willey, Rao, 1980). Spring cereal has been dominant in intercrops due to the higher rate of aggression (Ac), the competitiveness ratio (CRc) in spring cereals. In most cases, oat was characterised as the strongest weed suppresser in intercropping system (Table 6).

The cultivation conditions were less favourable for crop growth in 2008 (in loamy soil) and 2009 (in clay loam soil), therefore weed density increased by up to 1.5-2 times until the harvesting period. The weakest competitive ability of cereal was obtained during 2008 and 2009. The study showed that the role of intercropped pea in weed suppression was limited. $\mathrm{H}$. Hauggaard-Nielsen et al. (2008) indicate that a relative proportion of pea intercrop around $40-50 \%$ is needed in order to achieve a level of intraspecific competition.

\subsubsection{Weed suppression in sole crops and intercrops}

The ability of pea intercropped with cereal to suppress weed species was revealed only at the development of the grain at filling growth stage $(\mathrm{BBCH} 73)$ and during favorable crop growing conditions. The total number of weeds in intercrops was significantly reduced compared to pea sole crop at maturity stage (BBCH 73$)$ at both experimental sites (Table 7). 
The strongest weed suppression was observed in higher plant density intercrop and sole crop in Dotnuva. However, the number of weeds was 31.3-50.6\% lower in intercrop compared to pea sole crop. In lower density crops (Joniskelis), the number of weeds in intercrop was 22.4-31.0\% lower except for the oat sole crop and oat intercropped with pea. The oat displayed strong weed suppression capabilitieswith the number of weeds $72.5 \%$ lower in oat sole crop and $63.8 \%$ in oat/pea intercrop compared to pea sole crop. Comparison between cereal sole crops and intercrops showed a reduction in weed numbers in intercrop by an average $37.5 \%$, in sole crops by $44.8 \%$ at Dotnuva, and by 36.3 and $39.1 \%$, respectively in Joniskelis compared to pea sole crop. The number of weed species also significantly decreased except for pea/wheat (Dotnuva) and pea/triticale (Joniskelis) intercrops.

\begin{tabular}{|c|c|c|c|c|c|}
\hline \multirow{3}{*}{ Intercrop } & \multirow{2}{*}{ Year } & \multicolumn{2}{|c|}{ Loamy soil (Dotnuva) } & \multicolumn{2}{c|}{ Clay loam soil (Joniskelis) } \\
\cline { 2 - 6 } & & Ac & CRc & Ac & CRc \\
\hline \multirow{3}{*}{ P+SWi } & 2007 & 1.06 & 4.75 & 0.56 & 3.37 \\
\cline { 2 - 6 } & 2008 & 0.80 & 2.99 & 0.40 & 2.89 \\
\cline { 2 - 6 } & 2009 & 1.10 & 5.22 & 1.09 & 2.13 \\
\cline { 2 - 6 } & 2010 & - & - & 0.37 & 2.63 \\
\hline \multirow{4}{*}{ P+SBi } & 2007 & 1.09 & 6.52 & 0.96 & 7.84 \\
\cline { 2 - 6 } & 2008 & 0.20 & 1.51 & 0.91 & 3.88 \\
\cline { 2 - 6 } & 2009 & 0.92 & 7.90 & 1.50 & 3.09 \\
\cline { 2 - 6 } & 2010 & & & 0.57 & 2.28 \\
\cline { 2 - 6 } & 2007 & 1.25 & 4.89 & 1.22 & 15.63 \\
\cline { 2 - 6 } & 2008 & 1.17 & 2.90 & 1.15 & 5.45 \\
\cline { 2 - 6 } & 2009 & 1.41 & 9.89 & 1.26 & 4.67 \\
\cline { 2 - 6 } & 2010 & - & - & 0.85 & 5.25 \\
\hline \multirow{3}{*}{ P+STi } & 2007 & 0.78 & 3.65 & 0.38 & 2.44 \\
\cline { 2 - 6 } & 2008 & 0.70 & 4.05 & 1.52 & 1.33 \\
\cline { 2 - 6 } & 2009 & 1.99 & 7.92 & -0.17 & 0.54 \\
\hline
\end{tabular}

Note. Intercrop: $\mathrm{P}+\mathrm{SWi}$ - pea and spring wheat, $\mathrm{P}+\mathrm{SBi}$ - pea and spring barley; $\mathrm{P}+\mathrm{Oi}$ - pea and oat, $\mathrm{P}+\mathrm{STi}$ - pea and triticale.

Table 6. Plant aggressivety (Ac) and competition rate ( $\mathrm{CRc}$ ) in organically grown intercrops

The number of weeds observed during the cereal maturity stage $(\mathrm{BBCH} 73)$ varied compared to the weed number in spring (BBCH 32-36) (Table 8). Thus, weed population dynamics was influenced not only by the crop suppression ability, but also by the total weediness of crop and weed species. In Joniskelis, in the lower density pea sole crop, the number of weeds increased by $4.9 \mathrm{~m}^{-2}$, and in Dotnuva decreased by $3.1 \mathrm{~m}^{-2}$ during the period from emergence to cereal grain-filling growth stage. At Dotnuva, in the higher density crop, the total number of weeds decreased by $12.4-28.8 \mathrm{~m}^{-2}$ compared to the corresponding data in the spring. The variation of weed numbers during the growing season differed little between sole crop and intercrop (except oat sole crop and intercrop) with a decrease of 28.8 and $21.0 \mathrm{~m}^{-2}$, respectively. At Joniskelis, more marked differences between crops were determined; however, the suppression of weeds was weaker compared to the Dotnuva data. According to the spring weed density, the lowest suppression of weeds 
was in pea / barley intercrop and wheat and barley sole crops. Pea intercropped with wheat or triticale and triticale sole crop exhibited similar weed suppression; the number of weeds per $\mathrm{m}^{2}$ decreased by $9.8,12.7$ and 14.0 , respectively. The best ability to suppress weeds was shown by oat sole crop and oat intercropped with pea with a decrease in weeds per $\mathrm{m}^{2}$ by 24.4 and 30.1, respectively.

\begin{tabular}{|c|c|c|c|c|c|c|c|c|c|c|}
\hline \multirow{2}{*}{ Species } & \multirow{2}{*}{ Place } & \multicolumn{9}{|c|}{ Sole crops and intercrops (BBCH 73) } \\
\hline & & Ps & $\mathrm{P}+\mathrm{SWi}$ & $\mathrm{P}+\mathrm{SBi}$ & $\mathrm{P}+\mathrm{Oi}$ & P+STi & SWs & SBs & Os & STs \\
\hline \multirow{2}{*}{ Viola arvensis } & Dotnuva & 1.3 & 1.4 & 0.7 & 0.4 & 1.0 & 0.6 & 1 & $0.0^{*}$ & 0.7 \\
\hline & Joniskelis & 5.6 & 4.0 & 3.0 & $1.6^{* *}$ & 4.2 & 4.1 & 5.4 & $1.2^{* *}$ & 4.6 \\
\hline \multirow{2}{*}{ Veronica arvensis } & Dotnuva & 0.2 & 0.3 & 0.0 & 0.1 & 0.0 & 0.2 & 0.2 & 0.0 & 0.0 \\
\hline & Joniskelis & 15.3 & 10.2 & 10.8 & $2.9^{* *}$ & $8.2^{*}$ & 11.1 & 12.3 & $5.0^{* *}$ & $8.6^{*}$ \\
\hline \multirow{2}{*}{ Thlaspi arvense } & Dotnuva & 1.1 & $0.2^{* *}$ & $0.0^{* *}$ & $0.0^{* *}$ & $0.0^{* *}$ & $0.0^{* *}$ & $0.0^{* *}$ & $0.0^{* *}$ & $0.0^{* *}$ \\
\hline & Joniskelis & 3.7 & $1.3^{* *}$ & $0.2^{* *}$ & $0.0^{* *}$ & $0.8^{* *}$ & $0.5^{* *}$ & $0.2^{* *}$ & $0.0^{* *}$ & $0.5^{* *}$ \\
\hline \multirow{2}{*}{$\begin{array}{l}\text { Polygonum } \\
\text { persicaria }\end{array}$} & Dotı & 1.7 & 1.0 & $0.2^{* *}$ & 1.1 & $0.7^{*}$ & $0.6^{*}$ & $0.4^{*}$ & $0.3^{* *}$ & $0.1^{* *}$ \\
\hline & Joni & 0.0 & 0.0 & 0.0 & 0.0 & 0.0 & 0.0 & 0.0 & 0.0 & 0.0 \\
\hline \multirow{2}{*}{$\begin{array}{l}\text { Polygonum } \\
\text { aviculare }\end{array}$} & Dotnuva & 2.0 & $0.7^{*}$ & 2.2 & $0.4^{*}$ & 0.9 & $0.2^{* *}$ & 0.7 & $0.4^{*}$ & 0.7 \\
\hline & Joniskelis & 0.0 & 0.0 & 0.0 & 0.0 & 0.0 & 0.0 & 0.0 & 0.0 & 0.0 \\
\hline \multirow{2}{*}{ Galium aparine } & Dotnuva & 0.0 & 0.0 & 0.0 & 0.0 & 0.0 & 0.0 & 0.0 & 0.0 & 0.0 \\
\hline & Joniskelis & 4.4 & $2.2^{* *}$ & 3.5 & $1.7^{* *}$ & 3.4 & 3.1 & 2.5 & $1.3^{* *}$ & 3.1 \\
\hline \multirow{2}{*}{$\begin{array}{c}\text { Fallopia } \\
\text { convolvulus }\end{array}$} & Dotnuva & 1.2 & 0.8 & 0.8 & 0.6 & 1.1 & 1.7 & 0.2 & 1.8 & 1.3 \\
\hline & Joniskelis & 7.8 & 5.2 & 7.1 & $4.2^{*}$ & 6.6 & 5.3 & 5.9 & $4.2^{*}$ & 5.8 \\
\hline \multirow{2}{*}{ Stellaria media } & Dotnuva & 2.3 & 1.7 & 1.8 & 1.4 & 1.7 & 2.0 & 1.0 & $0.4^{*}$ & 1.0 \\
\hline & Joniskelis & 11.3 & 8.4 & 9.4 & $3.3^{* *}$ & $5.9^{* *}$ & $6.0^{* *}$ & 8.2 & $3.0^{* *}$ & $5.4^{* *}$ \\
\hline \multirow{2}{*}{$\begin{array}{l}\text { Chenopodium } \\
\text { album }\end{array}$} & Dotnuva & 37.6 & $27.0^{*}$ & $23.4^{\star *}$ & $22.0^{* *}$ & $28.0^{*}$ & $22.9^{* *}$ & $24.2^{* *}$ & $21.9^{* *}$ & $26.0^{* *}$ \\
\hline & Joniskelis & 7.2 & 7.0 & 6.1 & 5.1 & 9.3 & 6.1 & 8.1 & $1.7^{* *}$ & 6.2 \\
\hline \multirow{2}{*}{ Sonchus arvensis } & Dotnuva & 2.2 & 0.3 & 0.7 & 0.9 & 0.7 & 0.3 & 0.4 & 1.4 & 0.2 \\
\hline & Joniskelis & 6.1 & 3.4 & 5.3 & $1.4^{*}$ & 3.6 & $1.6^{*}$ & 3.9 & $0.5^{* *}$ & 4.1 \\
\hline \multirow{2}{*}{ Cirsium arvense } & Dotnuva & 2.8 & 0.7 & 3.2 & 3.1 & 2.9 & 0.2 & 1.1 & 0.4 & 3.6 \\
\hline & Joniskelis & 0.8 & 4.3 & 2.2 & 2.8 & 3.2 & $6.2^{*}$ & 3.0 & 0.7 & $4.8^{*}$ \\
\hline \multirow{2}{*}{$\begin{array}{c}\text { Total number of } \\
\text { weeds }\end{array}$} & Dotnuva & 54.7 & $35.7^{* *}$ & $33.2^{* *}$ & $30.3^{* *}$ & $37.6^{* *}$ & $29.4^{* *}$ & $30.0^{* *}$ & $27.0^{* *}$ & $34.3^{* *}$ \\
\hline & Joniskelis & 71.3 & $50.7^{*}$ & $54.2^{*}$ & $25.8^{* *}$ & $51.0^{*}$ & $49.4^{* *}$ & $55.3^{*}$ & $19.6^{* *}$ & $49.2^{* *}$ \\
\hline \multirow{2}{*}{$\begin{array}{c}\text { Number of weeds } \\
\text { species }\end{array}$} & Dotnuva & 6 & 5 & $3^{* *}$ & $4^{* *}$ & $5^{*}$ & $4^{* *}$ & $3^{* *}$ & $3^{* *}$ & $4^{* *}$ \\
\hline & Joniskelis & 9 & $7^{*}$ & $7^{*}$ & $5^{* *}$ & 8 & $7^{*}$ & $8^{*}$ & $4^{* *}$ & $8^{*}$ \\
\hline
\end{tabular}

Note. *differences are statistically significant as compared to the control at $P<0.05$, **-at $P<0.01$ Sole crop: Ps -pea, SWs - spring wheat, SBs - spring barley, Os -oat, STs - spring triticale; intercrop: $\mathrm{P}+\mathrm{SWi}$ - pea and spring wheat, $\mathrm{P}+\mathrm{SBi}$ - pea and spring barley; P+Oi - pea and oat, $\mathrm{P}+\mathrm{STi}-$ pea and triticale.

Table 7. Weed density (weed $\mathrm{m}^{-2}$ ) of the grain at filling growth stage (BBCH 73) of the most important species in sole crops and intercrops, data averaged over 2007-2010 


\begin{tabular}{|c|c|c|c|c|c|c|c|c|c|c|}
\hline \multirow{2}{*}{ Species } & \multirow{2}{*}{ Place } & \multicolumn{9}{|c|}{ Sole crops and intercrops (BBCH 73) } \\
\hline & & Ps & $\mathrm{P}+\mathrm{SW}$ & $\mathrm{P}+\mathrm{SBi}$ & $\mathrm{P}+\mathrm{Oi}$ & P+STi & SWs & SBs & Os & STs \\
\hline \multirow{2}{*}{ Viola arvensis } & Dotnu & -1.0 & -0.3 & -1.2 & -1.9 & -0.9 & -2.0 & -1.2 & -1.6 & -1.0 \\
\hline & Joniskelis & -0.2 & +0.5 & -0.4 & -1.3 & -1.0 & +0.6 & +0.7 & -1.3 & -1.3 \\
\hline \multirow{2}{*}{ Veronica arvensis } & Dotnuva & -0.9 & -0.3 & -0.6 & -0.2 & -1.2 & -0.4 & -0.2 & -0.4 & -0.7 \\
\hline & Joniskelis & +6.6 & +1.4 & +3.1 & -2.6 & -1.8 & +2.4 & +2.3 & -1.8 & +1.2 \\
\hline \multirow{2}{*}{ Thlaspi arvense } & Dotnuva & -2.6 & -1.5 & -0.9 & -0.9 & -0.8 & -1.0 & -0.7 & -1.6 & -0.4 \\
\hline & Jonis & -4.3 & -2.5 & -2.7 & -4.2 & -3.8 & -2.9 & -3.2 & -2.5 & -2.8 \\
\hline \multirow{2}{*}{$\begin{array}{l}\text { Polygonum } \\
\text { persicaria }\end{array}$} & Dotr & +0.5 & +0.3 & -0.4 & +0.4 & +0.5 & +0.5 & +0.2 & -0.4 & -0.2 \\
\hline & & - & 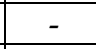 & 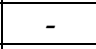 & - & - & - & 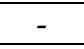 & - & - \\
\hline \multirow{2}{*}{$\begin{array}{l}\text { Polygonum } \\
\text { aviculare }\end{array}$} & Do & 1.0 & +0.6 & +0.8 & -0.2 & +0.3 & -0.5 & +0.1 & -0.4 & -1.0 \\
\hline & Jon & - & - & - & - & - & - & - & - & - \\
\hline \multirow{2}{*}{ Galium aparine } & & - & - & - & - & - & - & - & - & - \\
\hline & Joni & -4.4 & -3.8 & -2.3 & -5.3 & -3.2 & -1.9 & -2.7 & -2.6 & -1.8 \\
\hline \multirow{2}{*}{$\begin{array}{c}\text { Fallopia } \\
\text { convolvulus }\end{array}$} & Dot & -0.7 & -0.3 & -0.7 & -0.7 & +0.5 & -0.4 & -1.1 & -0.2 & +0.1 \\
\hline & Jonis & +2.5 & +1.0 & +2.5 & -1.3 & +0.3 & +1.8 & +2.9 & +0.4 & +0.4 \\
\hline \multirow{2}{*}{ Stellaria media } & Dot & -0.4 & -0.2 & -0.4 & -1.8 & -0.6 & -0.4 & -1.4 & -1.4 & -1.2 \\
\hline & Joniskelis & +0.7 & -3.8 & -1.6 & -9.3 & -3.4 & -4.5 & -6.4 & -6.5 & -11.5 \\
\hline \multirow{2}{*}{$\begin{array}{l}\text { Chenopodium } \\
\text { album }\end{array}$} & Dotr & +1.9 & -8.6 & -12.3 & -11.8 & -8.5 & -9.9 & -13.0 & -20.0 & -9.7 \\
\hline & Joniskelis & -1.3 & -0.8 & +0.7 & -0.8 & +4.6 & +1.9 & +2.3 & -2.8 & +1.4 \\
\hline \multirow{2}{*}{ Sonchus arvensis } & Dotr & +0.4 & -0.4 & +0.6 & 0.0 & -0.3 & 0.0 & -0.6 & 0.0 & -0.2 \\
\hline & Joniskelis & +5.4 & +3.1 & +4.8 & -0.1 & +1.4 & +0.9 & +3.6 & 0.0 & +3.7 \\
\hline \multirow{2}{*}{ Cirsium arvense } & Dotn & -0.1 & -0.1 & -0.3 & +0.1 & +0.6 & 0.0 & +0.6 & +0.3 & +0.4 \\
\hline & Joniskelis & +0.7 & +0.7 & +0.8 & +0.2 & +0.2 & +3.7 & +1.3 & +0.2 & +0.7 \\
\hline \multirow{2}{*}{$\begin{array}{c}\text { Total number of } \\
\text { weeds }\end{array}$} & Dotnuva & -3.1 & -12.4 & -18.2 & -21.0 & -12.9 & -17.2 & -18.2 & -28.8 & -16.7 \\
\hline & Joniskelis & +4.9 & -9.8 & +1.0 & -30.1 & -12.7 & -2.3 & -4.8 & -24.4 & -14.0 \\
\hline
\end{tabular}

Note. Sole crop: Ps - pea, SWs - spring wheat, SBs - spring barley, Os -oat, STs - spring triticale; intercrop: $\mathrm{P}+\mathrm{SWi}$ - pea and spring wheat, $\mathrm{P}+\mathrm{SBi}$ - pea and spring barley; $\mathrm{P}+\mathrm{Oi}$ - pea and oat, $\mathrm{P}+\mathrm{STi}-$ pea and triticale

Table 8 . The variation of weed numbers (weed $\mathrm{m}^{-2}$ ) of the most important species in sole crops and intercrops during growing season, data averaged over 2007-2010

At Joniskelis, the highest total mass of weeds was determined in pea sole crop and intercropped with triticale. At Dotnuva, the total dry matter (DM) of weeds in pea sole crop was $38.4 \%$ higher compared to the pea sole crop at Joniskelis (Table 9). At Dotnuva, Chenopodium album, Cirsium arvense, and Sonchus arvensis mass accounted for the largest share in the total weed mass. All cereal sole crops and intercrops significantly reduced weeds and the weed mass decreased by $72.0-90.7 \%$ compared to pea sole crop. At Joniskelis site, Cirsium arvense was spread unevenly in the experimental area; therefore, the total weed mass was substantially higher where this weed was present. The lowest total mass of weeds was determined in oat sole crop and pea intercropped with oat and barley.

The variation of weed total numbers and weight was determined by the response of different weed species to crop suppression. Weed species and their numbers at cereal maturity stage during maturity stage are presented in Tables 7,8 and 9. The species Viola arvensis, Veronica arvensis, Thlaspi arvense, Polygonum persicaria and Polygonum aviculare are 
considered less harmful for agricultural crops (Špokienè \& Povilionienè, 2003). The suppressing effect for Viola arvensis, Veronica arvensis was more pronounced in the lower density crop in Joniskelis. The number of these weed species slightly increased in the cereal sole crop compared to the pea intercropped with cereal. The number of these weeds significantly decreased in oat sole crop and intercropped with pea, and Veronica arvensis decreased even in triticale sole crop and intercropped with pea. Although the presence of Thlaspi arvense was low, the number of weeds was significantly reduced in all cereal sole crops and intercrops regardless of the site. At Dotnuva site, where Polygonum persicaria and Polygonum aviculare were found, the cereal sole crop suppressed these weeds slightly sronger compared to the pea intercrop. There were significantly fewer Polygonum aviculare plants in wheat, oat sole crops and intercropped with pea compared to the pea sole crop, whereas, Polygonum persicaria was suppressed by all cereal sole crops and some of their intercrops with pea.

The number of Viola arvensis was low at Dotnuva during cereal maturity stage compared to the findings in spring, (BBCH 32-36); the weed numbers were reduced. However, at Joniskelis, where the incidence of these weed species was higher, the number of weeds was reduced only in oat and triticale sole crops and intercropped with pea (by 1.3, 1.3 and 1.3, 1.0 weed $\mathrm{m}^{-2}$, respectively). The number of Viola arvensis increased in pea/wheat and wheat, barley sole crop. At Dotnuva, the number of Veronica arvensis during the gropwing season was reduced in all crops 0.2-1.2 weed $\mathrm{m}^{-2}$; however, at Joniskelis, the weed number increased in the majority of the crops. The number of Viola arvensis was reduced in oat sole crop $\left(1.8\right.$ weed $\left.\mathrm{m}^{-2}\right)$ and pea intercropped with oat $\left(2.8\right.$ weeds $\left.\mathrm{m}^{-2}\right)$, triticale $\left(1.8\right.$ weed $\left.\mathrm{m}^{-2}\right)$. The number of Thlaspi arvense was reduced in all crops $\left(0.4-1.6\right.$ weed $\left.\mathrm{m}^{-2}\right)$ at Dotnuva and at Joniskelis (2.5-4.3 weed $\left.\mathrm{m}^{-2}\right)$. The number of Polygonum persicaria and Polygonum aviculare increased in the majority of crops. The number of weeds most consistently decreased in oat and triticale sole crops. Viola arvensis, Veronica arvensis, Thlaspi arvense, Polygonum persicaria, Polygonum aviculare are less harmful, the mass of the weeds was low and significantly decreased in the majority of crops compared to pea sole crop.

Galium aparine and Fallopia convolvulus are common in crops. Their numbers significantly decreased in oat sole crop and intercropped with pea; Galium aparine was also decreased in pea intercropped with wheat compared to pea sole crop. Cleare advantages of intercrops compared to sole crops were not detected against these two harmful species of weeds.

A strong suppressive effect of crops on Galium aparine was identified during cereal maturity stage when the number of weeds declined by $1.9-5.3$ weed $\mathrm{m}^{-2}$ compared to the findings in spring. The advantages of intercrops were clear with oat, wheat and triticale intercrops reducing the number of Galium aparine by 5.3, 3.8 and 3.2 weed $\mathrm{m}^{-2}$, respectively, than sole cereal crops by 2.6, 1.9 and 1.8 weed $\mathrm{m}^{-2}$, respectively.The mass of Galium aparine decreased (22.9-96.1\%) in all crops, except for intercropped wheat. Significantly lower mass of these weeds was in the oat intercrop, and oat and barley sole crop compared to pea sole crop.

At Dotnuva, the number of Fallopia convolvulus during the growing season decreased in the majority of crops, except for tricticale sole crop and intercropped with pea. At Joniskelis, the number of these weeds increased during the whole growing season compared to the respective number of weeds in spring. The number of weeds markedly increased in intercropped barley and pea and wheat and barley sole crops. The number of Fallopia convolvulus decreased only in intercropped oat compared to the findings in spring. The 
experimental crops had greater influence on Fallopia convolvulus mass rather than number. At both experiment sites, intercrops and cereal sole crops significantly decreased the mass of this weed (by 70.6-98.7\% and 64.8-92.8\%, respectively) except for intercrop and sole crop of wheat (Dotnuva) and intercropped triticale (Joniskelis) compared to pea sole crop.

The incidence of Stellaria media was high at Joniskelis. Significantly fewer Stellaria media plants were recorded in cereal sole crop (except for spring barley) compared to pea sole crop. The number of this weed was significantly reduced by the intercrops of oat and triticale. The reduction in Stellaria media numbers during the cereal maturity stage was marked (regardless of their abundance) compared to the number of these weeds in spring, except for pea sole crop at Joniskelis. At both sites, this weed species was more suppressed by cereal sole crop than the intercrop. The highest reduction of Stellaria media was determined in these crops: pea / oats, oats, triticale (Dotnuva and Joniskelis) and barley sole crop (Dotnuva) compared to the respective weed numbers in spring. At Dotnova, the mass of Stellaria media was low and the influence of the crops was not significant, except for oat sole crop. The incidence of this weed was high at Joniskelis where the influence of crops on the reduction of weed mass was significant (37.7-94.8\%) compared to pea sole crop. The mass of Stellaria media was reduced by intercropped or sole oat. Also, this weed was suppressed by wheat, triticale sole crop and their intercrops with pea.

The incidence of Chenopodium album was high at Dotnuva (21.9-37.6 weeds $\mathrm{m}^{-2}$ ); all crops significantly reduced the number of this weed species compared to pea sole crop. At Joniskelis, the number of Chenopodium album was reduced only by oat sole crop. The variation of Chenopodium album numbers during the growing season showed that these weeds were not as intensively suppressed as other weed species at Dotnuva. The number of Chenopodium album reduced in intercrop and sole crop was 8.5-20.0 weeds $\mathrm{m}^{-2}$ compared to the respective weed numbers in spring. The number of this weed species slightly increased in pea sole crop. However, at Joniskelis, the number of Chenopodium album incresed in the majority of sole crops and intercrops, where 4-9 times fewer weeds emerged in spring. The number of weeds slightly decreased in wheat and oat intercrops and pea sole crop, but the weed incidence decreased most in oat sole crop $\left(2.8\right.$ weeds $\left.\mathrm{m}^{-2}\right)$. The investigated crops at both experimental sites reduced the mass of Chenopodium album by 71.6-93.4\% at Dotnuva and by $54.3-97.9 \%$ at Joniskelis compared to pea sole crop. The mass of this weed was lower in many cereal sole crops compared to intercrops.

Perennial weeds Sonchus arvensis and Cirsium arvense are more frequent on a clay loam soil, found at Joniskelis, compared to a loamy soil found at Dotnuva. At Joniskelis, Sonchus arvensis was more frequent in pea sole crop. The number of this weed significantly reduced in wheat, oat sole crops and intercropped with pea compared to pea sole crop. At Joniskelis, the number of Cirsium arvense decreased in all investigated crops, except for oat sole crop. Significantly higher numbers of this weed were found in spring wheat and triticale sole crop compared to pea sole crop. The trends of variation of this weed number were similar in Dotnuva. The crops were less suppressivefor perennial weeds than annual weed species observed in the experiment.

In spring, the number of Sonchus arvensis did not differ at either experimental site; however, variation of the weed numbers was noted. Consistent patterns of Sonchus arvensis variation were not determined in the higher density crops at Dotnuva. However, the number of weeds increased in all experimental crops, except for oat sole crop and intercropped with 
pea at Joniskelis. The influence of investigated crops on perennial weeds mass was not as marked as on annual weeds. At Joniskelis, the mass of Sonchus arvensis was significantly reduced in several crops including wheat and oat sole crops, and wheat and barley intercrops when compared to pea sole crop.

\begin{tabular}{|c|c|c|c|c|c|c|c|c|c|c|}
\hline \multirow{2}{*}{ pecies } & \multirow{2}{*}{ Place } & \multicolumn{9}{|c|}{ Sole crops and intercrops (BBCH 73) } \\
\hline & & Ps & $\mathrm{P}+\mathrm{SWi}$ & $\mathrm{P}+\mathrm{SBi}$ & $\mathrm{P}+\mathrm{Oi}$ & P+STi & SWs & SBs & Os & STs \\
\hline \multirow{2}{*}{ Viola arvensis } & & 0.16 & 0.16 & 0.05 & 0.06 & 011 & $0.03^{*}$ & 0.05 & $0.00^{*}$ & 0.08 \\
\hline & & 0.75 & $0.20^{* *}$ & $0.27^{* *}$ & $0.10^{* *}$ & 52 & 0.1 & $0.32^{*}$ & .02 & 0.44 \\
\hline \multirow{2}{*}{ Veronica arvensis } & & 0.02 & 0.02 & 0.00 & 0.01 & 0.00 & 0.0 & 0.01 & 0.0 & 0.00 \\
\hline & Joniskelis & 2.02 & $0.88^{* *}$ & $0.63^{* *}$ & $0.12^{* *}$ & $0.72^{* *}$ & $0.44^{* *}$ & $0.66^{* *}$ & $0.10^{* *}$ & $0.88^{* *}$ \\
\hline \multirow{2}{*}{ Thlaspi arvense } & Dot & 0.72 & $0.01^{*}$ & $0.00^{*}$ & $0.00^{*}$ & $0.00^{*}$ & $0.00^{*}$ & $0.00^{*}$ & $0.00^{*}$ & $0.00^{*}$ \\
\hline & Joni & 1.11 & $0.31^{*}$ & $0.0^{* *}$ & $0.00^{* *}$ & 0.42 & $0.02^{* *}$ & $0.01^{* *}$ & $0.00^{* *}$ & $0.01^{* *}$ \\
\hline \multirow{2}{*}{$\begin{array}{l}\text { Polygonum } \\
\text { persicaria }\end{array}$} & & 1.00 & $0.39 * *$ & $0.02^{* *}$ & $0.33^{* *}$ & $0.06^{* *}$ & $0.11^{* *}$ & $0.06^{* *}$ & $0.03^{* *}$ & $0.04^{* *}$ \\
\hline & & 0.00 & 0.00 & 0.00 & 00 & 00 & 0.0 & 0.00 & $\overline{00}$ & 0.00 \\
\hline \multirow{2}{*}{$\begin{array}{c}\text { Polygonum } \\
\text { aviculare }\end{array}$} & Dot & 2.16 & $0.44^{* *}$ & $0.50^{* *}$ & $0.14^{* *}$ & $0.14^{* *}$ & $0.03^{* *}$ & $0.10^{* *}$ & $0.11^{* *}$ & $0.14^{* *}$ \\
\hline & Joni & 0.00 & 0.00 & 0.00 & 0.00 & 0.00 & 0.00 & 0.00 & 0.00 & 0.00 \\
\hline \multirow{2}{*}{ Galium aparine } & Dotn & 0.00 & 0.00 & 0.00 & 0.00 & 0.00 & 0.00 & 0.00 & 0.00 & 0.00 \\
\hline & & 3.36 & 3.87 & 1.47 & $0.22^{* *}$ & 59 & 0 & $1.04^{*}$ & 0.1 & 1.39 \\
\hline \multirow{2}{*}{$\begin{array}{c}\text { Fallopia } \\
\text { convolvulus }\end{array}$} & & 1.53 & 0.51 & $0.21^{*}$ & $0.09^{* *}$ & $0.46^{*}$ & 0.86 & $0.02^{* *}$ & $0.20^{*}$ & $0.37^{*}$ \\
\hline & Joniskelis & 9.07 & $2.08^{* *}$ & $3.19^{* *}$ & $2.46^{* *}$ & 6.55 & $1.27^{* *}$ & $2.87^{* *}$ & $0.65^{\text {** }}$ & $2.36^{* *}$ \\
\hline \multirow{2}{*}{ Stellaria media } & Dot1 & 0.71 & 0.47 & 1.04 & 0.21 & 0.52 & 0.54 & 0.20 & $0.06^{*}$ & 0.12 \\
\hline & Joni & 8.64 & $5.38^{*}$ & $3.56^{* *}$ & $0.96^{* *}$ & $2.85^{\star \star}$ & 1.6 & $3.79 * *$ & $0.45^{\star *}$ & $2.02^{* *}$ \\
\hline \multirow{2}{*}{$\begin{array}{l}\text { Chenopodium } \\
\text { album }\end{array}$} & Dotr & 37.15 & $10.54^{* *}$ & $5.59 * *$ & $6.25^{* *}$ & $7.68^{* *}$ & $5.03^{* *}$ & $3.15^{* *}$ & $2.44^{* *}$ & $4.15^{* *}$ \\
\hline & Jonis & 7.94 & $2.41^{*}$ & $1.22^{* *}$ & $1.08^{* *}$ & 7.27 & $0.88^{* *}$ & $1.63^{* *}$ & $0.17^{* *}$ & $3.63^{*}$ \\
\hline \multirow{2}{*}{ Sonchus arvensis } & Dotnuva & 4.51 & 0.26 & 0.18 & 4.00 & 0.49 & 0.41 & 0.50 & 1.82 & 0.18 \\
\hline & Joniskelis & 2.97 & $0.19^{*}$ & $0.24^{*}$ & 1.58 & 3.33 & $0.40^{*}$ & 0.67 & $0.05^{* *}$ & 0.82 \\
\hline \multirow{2}{*}{ Cirsium arvense } & Dotnuva & 8.01 & 1.54 & 2.48 & 1.59 & 6.32 & $0.06^{*}$ & 0.92 & $0.25^{*}$ & 4.78 \\
\hline & Joniskelis & 0.66 & $19.37^{*}$ & 4.55 & 8.03 & $32.53^{*}$ & $30.30^{*}$ & 18.77 & 1.77 & $19.04^{*}$ \\
\hline \multirow{2}{*}{$\begin{array}{l}\text { Total mass of } \\
\text { weeds }\end{array}$} & Dotnuva & 56.89 & $14.61^{* *}$ & $10.27^{* *}$ & $12.72^{* *}$ & $15.96^{* *}$ & $7.34^{* *}$ & $5.36^{* *}$ & $5.27^{* *}$ & $10.02^{* *}$ \\
\hline & Joniskelis & 41.10 & 35.64 & $17.18^{*}$ & $15.28^{* *}$ & 60.44 & $38.84^{*}$ & 30.60 & $4.09 * *$ & 33.55 \\
\hline
\end{tabular}

Note. *differences are statistically significant as compared to the control at $P<0.05$, **-at $P<0.01$

Sole crop: Ps - pea, SWs - spring wheat, SBs - spring barley, Os -oat, STs - spring triticale; intercrop: $\mathrm{P}+\mathrm{SWi}$ - pea and spring wheat, $\mathrm{P}+\mathrm{SBi}$ - pea and spring barley; $\mathrm{P}+\mathrm{Oi}-$ pea and oat, $\mathrm{P}+\mathrm{STi}$ - pea and triticale

Table 9. The weed dry matter mass $\left(\mathrm{DM} \mathrm{g} \mathrm{m}^{-2}\right)$ of the most important species in sole crops and intercrops, data averaged over 2007-2010

At Joniskelis, the number of Cirsium arvense increased during the growing season in all investigated crops compared with its number in spring. At Dotnuva, an increase in the number of this weed was not consistent. The number of these weeds was slightly reduced by pea sole crop and intercropped with wheat and barley. More weeds germinated in cereal sole crop compared to intercrops at both expermental sites. The variation of Cirsium arvense 
mass differed between the experimental sites. At Dotnuva, Cirsium arvense mass was reduced in the wheat and oat sole crops of higher density but in other investigated crops, we established only a trend towards weed reduction. At Joniskelis, the mass of this perennial weed increased in all investigated crops, particularly in the wheat and triticale sole crops and their intercrops compared to pea sole crop.

Statistical data analysis showed that productive stem density had the greatest effect on weed suppression, while the effect of crop height and mass had a lesser affecting both soil conditions. In loamy soil (Dotnuva), the total number and mass of weeds were significantly related to the productive density $(\mathrm{r}=-0.922, P<0.01, \mathrm{r}=-0.909, P<0.01)$ within the range $109-478$ stems $\mathrm{m}^{-2}$. In clay loam soil (Joniskelis), where productive crop density was lower (81-355 stems $\mathrm{m}^{-2}$ ), the total number of weeds were significantly reduced by the height of crop $(\mathrm{r}=-0.830, P<0.01)$.

Annual weed species had variable responses to the crop density, height and mass. At Joniskelis, the number of Stellaria media was significantly reduced with increasing productive density, height and mass of crops $(\mathrm{r}=-0.685, P<0.05 ; \mathrm{r}=-0.952, P<0.01 ; \mathrm{r}=-$ $0.816, P<0.01$, respectively) and the mass of this weed (respectively $\mathrm{r}=-0.820, P<0.01 ; \mathrm{r}=-$ $0.834, P<0.01 ; \mathrm{r}=-0.720, P<0.05)$. At Dotnuva, in the treatments with a lower Stellaria media incidence the weed mass was most markedly reduced by crop height $(\mathrm{r}=-0.701, P<0.05)$. The investigated crops gave a good suppression of the following annual weeds as well: Veronica arvensis, Thlaspi arvense, Polygonum aviculare, Fallopia convolvulus. At Joniskelis, the number and mass of Fallopia convolvulus was significantly reduced as productive density of crops increased $(r=-0.759, P<0,05 ; \mathrm{r}=-0.930, P<0.01$, respectively). The number of these climbing weeds was also significantly reduced by the height and mass of crops $(\mathrm{r}=-0.818$, $P<0.01 ; \mathrm{r}=-0.799, P<0.01$, respectively).

All crops competed well with Veronica arvensis. The number of this weed was significantly reduced by the height and mass of the crop ( $\mathrm{r}=-0.862, P<0.01 ; \mathrm{r}=-0.681, P<0.05$, respectively), but weed mass was reduced by the productive density and height of crops ( $\mathrm{r}=$ - 0.789, $P<0.05 ; \mathrm{r}=-0.695, P<0.05$, respectively). At Dotnuva, a consistent pattern was not determined due to lower incidence of Fallopia convolvulus and Veronica arvensis. For Thlaspi arvense, the findings at the Dotnuva site were similar to those at Joniskelis. The number and mass of Thlaspi arvense were significantly reduced by the productive density of crops $(\mathrm{r}=-$ 0.823, $P<0.01 ; \mathrm{r}=-0.821, P<0.01$, Dotnuva and $\mathrm{r}=-0.821, P<0.01 ; \mathrm{r}=-0.889, P<0.01$, respectively at Joniskelis). The data of suppression are less consistent for Galium aparine and Chenopodium album which are harmful weed species in this region. At Dotnuva, in denser crops, Chenopodium album numbers and mass were significantly reduced by the productive density of crops $(\mathrm{r}=-0.867, P<0.01 ; \mathrm{r}=-0.873, P<0.01$, respectively). At Joniskelis, in thinner crops, productive density of crops significantly reduced only weed mass $(r=-0.783, P<0.05)$.

Galium aparine is a climbing weed; therefore, the spread of this weed was negatively influenced by increasing productive stem numbers and crop height $(\mathrm{r}=-0.671, P<0.05 ; \mathrm{r}=-$ $0.670, P<0.05$, respectively). The data of perennial weeds showed that Sonchus arvensis was suppressed more than Cirsium arvense. At Joniskelis, the spread of Sonchus arvensis depended on the density $(\mathrm{r}=-0.719, P<0.05)$, height $(\mathrm{r}=-0.814, P<0.01)$ and mass $(\mathrm{r}=-$ 0.754, $P<0.01)$ of crops. Also, the mass of Sonchus arvensis decreased due to increasing productive density of crops $(\mathrm{r}=-0.731, P<0.05)$. At Dotnuva, Sonchus arvensis spread less; 
therefore, the relationship was determined only between the number of this weed and productive density of crops $(\mathrm{r}=-0.670, P<0.05)$. At Dotnuva, a strong relationship $(\mathrm{r}=-$ $0.856, P<0.01)$ was established between Cirsium arvense numbers and productive density of crops.

The relationship established between the total number and mass of weeds and intercrop competitive ability indicators (aggressivity - Ac; competition rate - CRc) showed that, with increasing competition rate of intercrops, weed incidence declined. This relationship was determined only at Joniskelis where the productive density was lower, the variation rate of CRc was higher, and weed species diversity and numbers were increased. With changing competition rates (0.54-15.63), weed number and mass declined by a linear inverse relationship. The correlation was medium $(r=-0.551, P<0.05 ; \mathrm{r}=-0.5031, P<0.05$, respectively).

Researchers from five countries: Denmark, United Kingdom, France, Germany and Italy investigated the influence of pea and barley intercrop sown at different ratios - 45 peas and 150 barley plants $\mathrm{m}^{-2}$, and 90 peas and 150 barley plants $\mathrm{m}^{-2}$ - on dry matter of weeds. The control of weeds was similar in sole barley and in intercrops, and no difference was established between the substitutive and the additive intercrops (Dibet et al., 2006). Researchers report the advantages of various intercropping managements such as pea with wheat against weeds (Szumigalski \& van Acker, 2005), pea with barley (Hauggaard-Nielsen et al., 2006), and pea with oats (Rauber et al., 2001). Diversity of weeds was decreased in intercrops in comparison with sole crop (Gharineh \& Moradi Telavat, 2009). Like cultivated plants, weeds obtain nutrients through root uptake from the soil solution. As a result, weeds and crops compete for space, nutrients, water and light. Both weeds and crop plants are similar in chemical composition; therefore, weeds can accumulate similar or even higher amounts of nutrients than crops (Lazauskas, 1990). Nitrogen increases weed and crop biomass (Kristensen et al., 2008). Peas use little nitrogen from the soil since they can fix atmospheric nitrogen for use. As a result, peas provide good conditions for weed growth, especially for high nitrogen demanding weed species. Dibet et al. (2006) reported a lower nitrogen concentration, $0.8 \mathrm{~g} \mathrm{~m}^{-2}$, in weed mass due to competition between weed and cereal in intercrops compared to pea sole crop.

Statistical analyses of sole crop and intercrop grain yields and weed numbers and variation are presented in Figure 1.

Strong, inversely proportional relationships were established between grain yield and total weed number, and between grain yield and weed number variation during the growing season. This means that the number of weeds and their variation conversely affected crop yield. These relationships were determined only in lower density crops in clay loam soil (Joniskelis) when weed incidence markedly increased. The analysis of the statistical data suggested that an increase in the total weed number by one weed (regardless of the species) resulted in a grain yield reduction by $27.3 \mathrm{~kg}^{-1}$ (Figure 1a). The investigated crop competition characteristics describe the relationship between crop yields and weed number variation during the growing period. The grain yield changed $18.8 \mathrm{~kg} \mathrm{ha}^{-1}$ by an inverse trend when changing one weed (Figure $1 \mathrm{~b}$ ). The relationship between grain yield and total weed mass was not significant $(\mathrm{r}=-0.564, P>0.05)$. This relationship could determine perennial weed mass, which was especially high and the weeds were spread unevenly. It can be maintained that, in clay loam soil (Joniskelis), the majority of the investigated crops 
were not strongly competitive and, during maturity stage, there remained 71.3-49.2 weeds $\mathrm{m}^{-2}$ in crops which had a negative impact on grain yield. Oat sole crop and intercropped with pea markedly differed from other investigated crops in that 19.6 and 25.8 weeds $\mathrm{m}^{-2}$ remained during the maturity stage. At Dotnuva, this relationship was not determined. The number of weeds decreased by $54.7-27.0 \mathrm{~m}^{-2}$ and such weed incidence had no significant negative effect on the crop productivity. This shows that sustainable plant communities are formed under organic farming conditions.
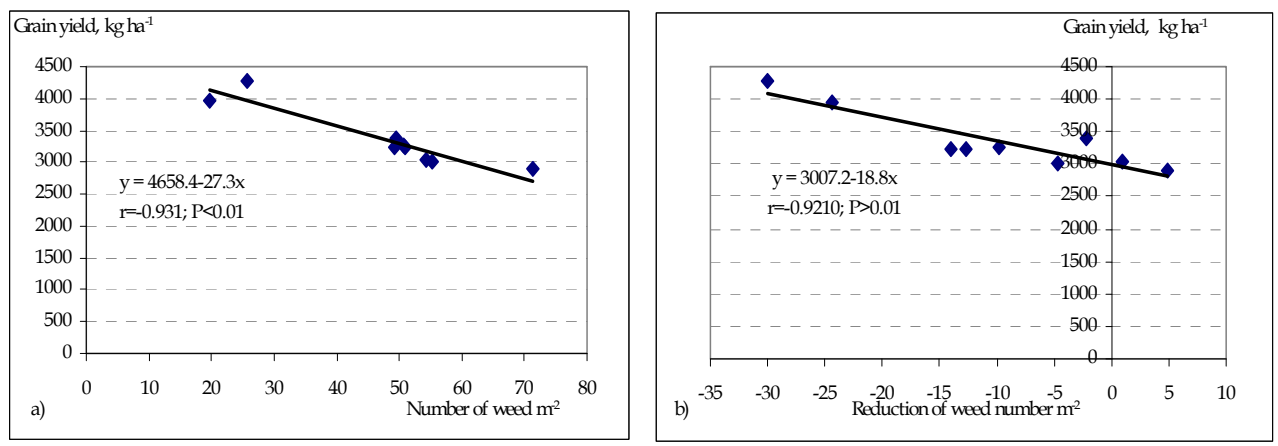

Fig. 1. The correlation between grain yield of sole crop, intercrop and total number of weeds (a), and their variation during grain-filling stage (BBCH 73) (b),Joniskelis 2007-2010

\subsubsection{The effect of intercrops on subsequent crops in a crop rotation}

During 2007-2010, studies were conducted at Joniskelis to assess the incidence of weeds in the intercropping system. The studies were set up during the transitional period from conventional to organic farming. The dynamics of weed germination (at crop growth stage $\mathrm{BBCH}$ 32-36) in the crop rotation is summarized in Table 10. In the spring of 2007, the highest number of weeds was in the pea sole crop. In various spring cereals and their intercrops with pea, weed density decreased by 1.7-35.7\% compared to pea sole crop.

The averaged data suggested that the number of weeds in intercrops was slightly lower compared to cereal sole crops. After various sole cereal crops and intercrops with pea, as pre-crop to spring wheat (2008), the number of weeds in spring wheat was similar to that in the pre-crop (2007); however, in spring wheat grown after pea, weed numbers were the lowest. In spring wheat grown after various cereal sole crops and their intercrops with pea, the number of weeds increased by 3.6-69.4\% compared with spring wheat grown after pea sole crop. In the third year (2009), under an organic cropping system, weed density significantly increased in sole cereal crops and their intercrops with pea. Weed germination was 1.8 times higher than that in 2007 or 2008. The number of weeds in pea sole crops increased by $50.7 \mathrm{~m}^{-2}$ on average, with an increase of $26.5 \mathrm{~m}^{-2}$ in intercrops and $12.5 \mathrm{~m}^{-2}$ in cereal sole crop compared to the 2008 spring period. The number of weeds was significantly $(\mathrm{P}<0.01)$ influenced by crops. Like in 2007, the highest number of weeds was in pea sole crop. The number of weeds decreased by $17.1-53.3 \%$ in all other crops tested. Weed germination was significantly lower in oat intercrop and cereal sole crops. The variation of total weed numbers in 2010 was low in winter wheat grown after pea, cereal sole crops and intercrops compared to that in 2009. However, weed germination depended on different 
pre-crops. Weed density decreased by $23.3 \mathrm{~m}^{-2}$ in wheat grown after pea sole crop, but weed numbers increased on average by 3.3 and $8.6 \mathrm{~m}^{-2}$, respectively, after intercrops and cereal sole crops compared to the 2009 spring period. Different pre-crops did not have any significant influence on weed density in winter wheat.

\begin{tabular}{|c|c|c|c|c|c|c|c|}
\hline \multicolumn{2}{|c|}{ Rotation } & $\begin{array}{c}\text { Total } \\
\text { Intercrop and sole } \\
\text { crop 2007 }\end{array}$ & $\begin{array}{c}\text { Spring } \\
\text { wheat } \\
\text { (SWs) 2008 }\end{array}$ & $\begin{array}{c}\text { Intercrop and sole crop } \\
2009\end{array}$ & $\begin{array}{c}\text { Winter } \\
\text { wheat } \\
\text { (WWs) } \\
2010\end{array}$ & $\begin{array}{c}\text { Averaged } \\
\text { over crop } \\
\text { rotation } \\
\text { number } \\
\text { over the } \\
\text { year }\end{array}$ \\
\hline crop & \multicolumn{2}{|c|}{ weed m-2 } & crop & \multicolumn{5}{c|}{ weed m-2 } \\
\hline Ps & 35.3 & 19.3 & Ps & 70.0 & 46.7 & 171.3 & 42.8 \\
\hline P+SWi & 26.0 & 20.0 & P+Oi & $51.3^{*}$ & 62.0 & 159.3 & 39.8 \\
\hline P+SBi & 22.7 & 32.7 & P+STi & 58.0 & 58.0 & 171.3 & 42.8 \\
\hline P+Oi & 34.7 & 24.7 & P+SWi & 54.0 & 66.0 & 179.3 & 44.8 \\
\hline P+STi & 26.0 & 34.7 & P+SBi & 54.7 & 45.3 & 160.7 & 40.2 \\
\hline SWs & 27.3 & 27.3 & Os & $35.3^{* *}$ & 47.3 & $137.3^{* *}$ & 34.3 \\
\hline SBs & 34.7 & 28.7 & STs & $52.7^{*}$ & 52.7 & 168.7 & 42.2 \\
\hline Os & 24.0 & 28.0 & SWs & $32.7^{* *}$ & 47.3 & $132.0^{* *}$ & $33.0^{*}$ \\
\hline STs & 27.3 & 32.7 & SBs & $46.0^{* *}$ & 54.0 & 160.0 & 40.0 \\
\hline Mean & 28.7 & 27.6 & Mean & 50.5 & 53.3 & 160.0 & 40.0 \\
\hline intercrop & 27.4 & 28.0 & intercrop & 54.5 & 57.8 & 167.7 & 41.9 \\
\hline sole crop & 28.3 & 29.2 & sole crop & 41.7 & 50.3 & 149.5 & 37.4 \\
\hline
\end{tabular}

Note. *differences are statistically significant as compared to the control at $P<0.05$, **-at $P<0.01$

Sole crop: Ps - pea, SWs - spring wheat, SBs - spring barley, Os -oat, STs - spring triticale; intercrop:

$\mathrm{P}+\mathrm{SWi}$ - pea and spring wheat, $\mathrm{P}+\mathrm{SBi}$ - pea and spring barley; $\mathrm{P}+\mathrm{Oi}-$ pea and oat

Table 10. The dynamics of weed germination in the crop rotation with cereal sole crop and intercrop, 2007-2010, Joniskelis

Over a four-year period, the total number of weeds ranged from 132.0 to $179.3 \mathrm{~m}^{-2}$. In the crop rotation with intercrops, the weed germination was $12.2 \%$ or 18.2 weeds $\mathrm{m}^{-2}$, higher compared to the crop rotation with cereal sole crops. Significantly lower weed germination was seen in the four-course crop rotation, including oat sole crop: Os - SWs -SWs - WWs; SWs - SWs - Os - WWs, compared to the rotation including pea sole crop (Ps - SWs - Ps WWs).

The number of weeds and their variation during cereal maturity stage $(\mathrm{BBCH} 73)$ are presented in Table 11. During the first experimental year (2007), the intercrops and sole crops were competitive and gave a good suppression of weeds. The number of weeds decreased by $12-28 \mathrm{~m}^{-2}$ compared to that in spring. According to the averaged data, the intercrops and sole crops did not differ markedly in their ability to suppress weeds. The number of weeds decreased by $20.9-79.1 \%$ in cereal sole crops and intercrops compared to pea sole crop. Significantly lower numbers of weeds were found in wheat and oat intercrops and oat sole crops during the cereal maturity stage. At the cereal maturity stage, the number of weeds was on average 4.3 times higher in spring wheat (2008) grown after various cereal 
sole crops and intercrops compared to the corresponding period in 2007. Although in 2008 weed emergence was similar to that in 2007, the number of weeds in spring wheat increased by an average 1.7 times compared to that during the spring period.

Averaged data showed that in the wheat crop grown after intercrops, the number of weeds increased by $20 \mathrm{~m}^{-2}$, by $17.9 \mathrm{~m}^{-2}$ after sole crops and by $24.7 \mathrm{~m}^{-2}$ after pea, compared with the respective data in spring. Comparison of the effects of various pre-crops on weed incidence in spring wheat showed that the number of weeds declined in pea/oat, sole barely and oat crops (by 6.1, 19.8 and 15.2\%, respectively), compared with pea sole pre-crop. However, these differences were not significant.

In 2009, the number of weeds further increased. In sole cereal crops and intercrops, during the cereal maturity stage, the number of weeds was $97.1 \mathrm{~m}^{-2}$, which was 2 times higherthan during the same period in 2008, and 1.9 times more than in spring (2009). Compared with the spring period, weed numbers in pea crop increased by $76 \mathrm{~m}^{-2}$, in intercrops by $49.3-54.0 \mathrm{~m}^{-2}$ (except for pea/oat crop) and in sole cereal crops by 53.3-77.3 $\mathrm{m}^{-2}$ (except for oat crop). Weed numbers declined in pea/oat and sole oat crops by 2.0 and $6.6 \mathrm{~m}^{-2}$ or 3.9 and $18.7 \%$ respectively, compared with the respective data in spring. All intercrops and cereal sole crops significantly decreased weed numbers by $15.5-80.3 \%$, except for the sole triticale crop, compared with pea crop. Averaged data suggest that sole cereal crops suppressed weeds slightly more than intercrops. The lowest weed incidence was recorded in pea/oat and sole oat crops.

\begin{tabular}{|c|c|c|c|c|c|c|c|}
\hline \multicolumn{6}{|c|}{ Rotation } & \multirow{2}{*}{$\begin{array}{c}\text { Total weed } \\
\text { number } \\
\text { during } \\
\text { crop } \\
\text { rotation }\end{array}$} & \multirow[b]{2}{*}{$\begin{array}{c}\text { Averaged } \\
\text { number } \\
\text { over the } \\
\text { year }\end{array}$} \\
\hline $\begin{array}{r}\text { Intercrop } \\
\text { crop }\end{array}$ & $\begin{array}{l}\text { d sole } \\
77\end{array}$ & \begin{tabular}{|c|} 
Spring \\
wheat \\
$(\mathrm{SWs}) 2008$
\end{tabular} & \multicolumn{2}{|c|}{$\begin{array}{l}\text { Intercrop and sole } \\
\text { crop } 2009\end{array}$} & $\begin{array}{c}\text { Winter } \\
\text { wheat } \\
\text { (WWs) } \\
2010\end{array}$ & & \\
\hline Crop & \multicolumn{2}{|c|}{ weed $\mathrm{m}^{-2}$} & crop & \multicolumn{4}{|c|}{ weed $\mathrm{m}^{-2}$} \\
\hline Ps & 17.7 & 44.0 & Ps & 146.0 & 91.3 & 299.0 & 74.8 \\
\hline $\mathrm{P}+\mathrm{SWi}$ & $8.7^{*}$ & 51.3 & $\mathrm{P}+\mathrm{Oi}$ & $49.3^{* *}$ & $66.7^{* *}$ & $176.0^{* *}$ & $44.0^{* *}$ \\
\hline $\mathrm{P}+\mathrm{SBi}$ & 10.7 & 53.7 & $\mathrm{P}+\mathrm{STi}$ & $112.0^{*}$ & 110.0 & 286.3 & 71.6 \\
\hline $\mathrm{P}+\mathrm{Oi}$ & $6.7^{* *}$ & 41.3 & $\mathrm{P}+\mathrm{SWi}$ & $103.3^{*}$ & 112.7 & $264.0^{*}$ & 66.0 \\
\hline $\mathrm{P}+\mathrm{STi}$ & 13.3 & 45.7 & $\mathrm{P}+\mathrm{SBi}$ & $108.7^{*}$ & 88.7 & $256.3^{* *}$ & 64.1 \\
\hline SWs & 11.0 & 58.7 & Os & $28.7^{* *}$ & 70.0 & $168.3^{* *}$ & $42.1^{* *}$ \\
\hline SBs & 14.0 & 35.3 & STs & $106.0^{*}$ & 102.0 & $257.3^{* *}$ & 64.3 \\
\hline Os & $3.7^{* *}$ & 37.3 & SWs & $96.7^{* *}$ & 80.7 & $218.3^{* *}$ & $54.6^{*}$ \\
\hline STs & 10.0 & 45.0 & SBs & 123.3 & 88.7 & $267.0^{*}$ & 66.8 \\
\hline Mean & 10.6 & 45.8 & Mean & 91.7 & 90.1 & 243.6 & 60.9 \\
\hline Intercrop & 9.9 & 48 & intercrop & 93.3 & 94.5 & 245.7 & 61.4 \\
\hline sole crop & 9.7 & 44.1 & sole crop & 88.7 & 85.4 & 227.8 & 56.9 \\
\hline
\end{tabular}

Note. *differences are statistically significant as compared to the control at $P<0.05,{ }^{* *}$-at $P<0.01$ Sole crop: Ps - pea, SWs - spring wheat, SBs - spring barley, Os -oat, STs - spring triticale; intercrop: $\mathrm{P}+\mathrm{SWi}$ - pea and spring wheat, $\mathrm{P}+\mathrm{SBi}$ - pea and spring barley; P+Oi - pea and oat

Table 11. The variation of weed numbers in the crop rotation with intercrops and sole crops at cereal maturity stage, 2007-2010, Joniskelis 
In 2010, at the winter wheat maturity stage, weed numbers differed little from that in 2009. However, compared with the spring period, weed numbers increased an average of 1.7 times. Averaged data indicate that the greatest increase in weed numbers occurred in winter wheat grown after pea; a smaller increase occurred after intercrops and sole crops. Compared with pea, significantly lower weed numbers were determined in winter wheat crop grown after pea/oat intercrop.

Various crop rotations had significant effects $(P<0.01)$ on the total weed number during cereal maturation stage. The highest number of weeds over a four-year period was established in the crop rotation with pea (Ps - SWs - Ps - WWs). Inclusion of semi-leafless pea in the crop rotation tended to increase crop weed incidence. In all other crop rotations with sole cereal crops or pea/cereal intercrops, the total weed incidence significantly declined by 10.7-43.7\% (except for the crop rotation: P+SBi - SWs - P+STi - WWs), compared with the crop rotation with pea (Ps - SWs - Ps - WWs). Averaged over one year, significantly lower weed incidence was in the following crop rotations: P+SWi - SWs - P+Oi - WWs; SWs - SWs - Os - WWs and Os - SWs - SWs - WWs, compared with the crop rotation including pea.

Weed mass variation in different crops at cereal maturation stage $(\mathrm{BBCH} 73)$ is presented in Table 12. For the first year (2007) in intercrops and sole cereal crops, the weed incidence was low; consequently, their mass was low. Compared with pea crop, in all intercrops and sole cereal crops weed mass was significantly lower (61.1-97.3\%). The lowest weed mass was recorded in oat and its intercrops with pea. The mass per weed varied in a similar way (except for pea/triticale crop). Averaged data suggest that higher total weed mass and mass per weed was in intercrops, compared with sole crops.

In the next year (2008), in spring wheat crop grown after different pre-crops, weed mass increased by 1.9 times. Different pre-crops exerted varying effects. When spring wheat had been grown after pea, the total weed mass declined by 2.0 times; after intercrops, it increased by 3.0 times and after sole cereals it increasedby 3.7 times, compared with respective weed mass in 2007. Pea/barley and pea/triticale intercrops tended to increase weed mass in spring wheat, compared with pea pre-crop. Other crops, as pre-crops, reduced weed mass. Averaged data indicate that the highest mass per weed was in spring wheat grown after pea sole crop; weed mass was lower after intercrops and it was the lowest after sole cereal crops. Pea/oat intercrop and sole spring wheat crop as pre-crops significantly reduced mass per weed compared with pea as pre-crop. Reduction of mass per weed decreased viability and number of mature seeds (Lazauskas, 1990; Liebman \& Davis, 2000).

In the third year of the crop rotation, when growing various species of cereals and their intercrops with pea, the total weed number increased by an average of 3 times, compared with the average total weed mass in 2008, or by 5.6 times, compared with 2007. Many of the tested crops significantly reduced weed mass by 70.4-96.3\% (except for pea/triticale and triticale crops) compared with sole pea crop. Significantly lower mass per weed was determined in sole cereal crops (except for triticale) and pea/barley crops, compared with pea crop.

In the final year of the experiment (2010), in the winter wheat crop, total weed mass increased by an average of $29.6 \%$ compared with that in 2009 . After different pre-crops, total weed mass was variable. In winter wheat grown after pea, total weed mass declined by 
$34.3 \%$, after intercrops and sole crops it increased by 23.7 and $94.3 \%$, respectively, compared with the respective data in 2009. Significantly lower total weed mass and mass per weed in winter wheat was recorded when it was grown after pea/oat and sole oat crops.

\begin{tabular}{|c|c|c|c|c|c|c|c|c|c|c|}
\hline \multicolumn{10}{|c|}{ Rotation } & \multirow{4}{*}{\begin{tabular}{|c|} 
Total \\
weed \\
mass \\
over \\
crop \\
rotation \\
$(\mathrm{g})$ \\
\end{tabular}} \\
\hline \multicolumn{3}{|c|}{$\begin{array}{c}\text { Intercrop and sole crop } \\
2007 \\
\end{array}$} & \multirow{2}{*}{\multicolumn{2}{|c|}{$\begin{array}{l}\text { Spring wheat } \\
\text { (SWs) } 2008 \\
\end{array}$}} & \multicolumn{3}{|c|}{$\begin{array}{l}\text { Intercrop and sole crop } \\
2009\end{array}$} & \multicolumn{2}{|c|}{$\begin{array}{l}\text { Winter wheat } \\
\text { (WWs), } 2010\end{array}$} & \\
\hline \multirow[b]{2}{*}{ crop } & \multicolumn{2}{|c|}{ weed mass } & & & \multirow[b]{2}{*}{ crop } & \multicolumn{4}{|c|}{ weed mass } & \\
\hline & $\begin{array}{l}\text { total } \\
\left(\mathrm{g} \mathrm{m}^{-2}\right)\end{array}$ & $\begin{array}{c}\text { single } \\
\text { weed }(\mathrm{g})\end{array} \mid$ & $\begin{array}{l}\text { total } \\
\left(\mathrm{g} \mathrm{m}^{-2}\right)\end{array}$ & $\mid \begin{array}{c}\text { single } \\
\text { weed }(\mathrm{g})\end{array}$ & & $\begin{array}{l}\text { Total } \\
\left(\mathrm{g} \mathrm{m}^{-2}\right)\end{array}$ & $\begin{array}{c}\text { single } \\
\text { weed }(\mathrm{g})\end{array} \mid$ & $\begin{array}{l}\text { total } \\
\left(\mathrm{g} \mathrm{m}^{-2}\right)\end{array}$ & $\left|\begin{array}{c}\text { single } \\
\text { weed }(\mathrm{g})\end{array}\right|$ & \\
\hline Ps & 23.6 & 1338 & 12.11 & 275 & Ps & 67.27 & 61 & 44. & 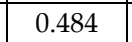 & 147.2 \\
\hline $\mathrm{P}+\mathrm{SWi}$ & $1.77^{* *}$ & $0.204^{* *}$ & 10.02 & 0.195 & $\mathrm{P}+\mathrm{Oi}$ & $12.44^{* *}$ & .252 & $16.51^{* *}$ & $0.248^{*}$ & $40.74^{* *}$ \\
\hline $\mathrm{P}+\mathrm{SBi}$ & $3.21^{*}$ & $\ldots$ & 13.58 & 0.253 & P+STi & 71.80 & 641 & 41.1 & 0.374 & 129.69 \\
\hline $\mathrm{P}+\mathrm{Oi}$ & $1.23^{* *}$ & $0.184^{* *}$ & $7.12^{*}$ & $0.172^{*}$ & $\mathrm{P}+\mathrm{SWi}$ & $19.93^{* *}$ & 0.193 & 60.33 & 0.535 & $88.61^{*}$ \\
\hline P+STi & $9.19 * *$ & 0.689 & 14.73 & 0.322 & $\mathrm{P}+\mathrm{SBi}$ & $18.61^{* *}$ & $0.171^{*}$ & 33.97 & 0.383 & $76.5^{* *}$ \\
\hline SWs & $2.71^{* *}$ & $0.247^{* *}$ & $6.66^{*}$ & $0.113^{*}$ & Os & $2.50^{* *}$ & $0.087^{* *}$ & $13.72^{* *}$ & $0.196^{* *}$ & $25.59^{* *}$ \\
\hline SBs & $2.57^{* *}$ & $0.184^{* *}$ & 7.63 & 0.216 & STs & 51.03 & 0.481 & 52.25 & 0.512 & 113.48 \\
\hline Os & $0.63^{* *}$ & $0.171^{\text {** }}$ & 8.80 & 0.236 & SWs & $9.05^{* *}$ & $0.094^{*}$ & 37.06 & 0.459 & $55.54^{* *}$ \\
\hline STs & $2.91^{* *}$ & $0.291^{* *}$ & 9.22 & 0.205 & SBs & $15.01^{* *}$ & $0.122^{*}$ & 47.78 & 0.539 & $74.92^{* *}$ \\
\hline Mean & 5.32 & 0.401 & 9.99 & 0.221 & Mean & 29.74 & 0.278 & 38.54 & 0.414 & 83.59 \\
\hline intercrop & 3.85 & 0.345 & 11.36 & 0.236 & intercrop & 30.70 & 0.314 & 37.98 & 0.385 & 83.89 \\
\hline sole crop & 2.21 & 0.223 & 8.08 & 0.193 & sole crop & 19.40 & 0.196 & 37.70 & 0.427 & 67.38 \\
\hline
\end{tabular}

Note. *differences are statistically significant as compared to the control at $P<0.05$, **-at $P<0.01$

Sole crop: Ps - pea, SWs - spring wheat, SBs - spring barley, Os -oat, STs - spring triticale; intercrop:

$\mathrm{P}+\mathrm{SWi}$ - pea and spring wheat, $\mathrm{P}+\mathrm{SBi}$ - pea and spring barley; $\mathrm{P}+\mathrm{Oi}$ - pea and oat

Table 12. The variation of weed mass in the crop rotation with intercrops and sole crops during cereal maturity stage, 2007-2010, Joniskelis

Summarised data show that in cultivated heavy loam Cambisol, during the transition period from an input-intensive to an organic cropping system, weeds emerged more intensively in the third and fourth years of the crop rotation. Averaged data evidence that, in the crop rotations with sole cereal crops and intercrops, weed numbers annually increased. In the crop rotation with pea, the pea promoted weed emergence; pea as pre-crop effect on wheat reduced weed emergence. During the four year, significantly fewer weeds emerged in the crop rotation with sole oat crop.

During the cereal maturity stage, weed numbers and mass were more markedly influenced by sole cereal crops and their intercrops with pea compared with their effect as pre-crops. In the first year, compared with the spring period, weed numbers during the growing season markedly declined; over the following years, weeds were suppressed less and their numbers increased. Cereal sole crops and intercrops had a greater suppression of weeds during the growing season; therefore, their numbers per rotation (except for the crop rotation $\mathrm{P}+\mathrm{SBi}-$ SWs - P+STi + WWs) and mass (also except for the crop rotation P+SBi - SWs - P+STi WWs and SBi - SWs -STi - WWs) were significantly lower compared with the crop rotation with pea. Over the four years, during the cereal maturity stage in the crop rotations with intercrops, the total number of weeds was an average of $17.9 \mathrm{~m}^{-2}$ higher and $55.3 \mathrm{~m}^{-2}$ lower, 
and the total weed mass by $16.51 \mathrm{~g} \mathrm{~m}^{-2}$ higher and $63.31 \mathrm{~g} \mathrm{~m}^{-2}$ lower, compared with the crop rotations with sole cereals or pea. Averaged data indicate that for any one year, significantly fewer weeds were in the crop rotation including oat or its intercrop with pea. Literature provides data on allelopathy effects against weeds due to direct or indirect release of chemicals from live or dead plants (including microorganisms) (Bhadoria, 2011). The effect of sole oat crop against weeds was longer-lasting than that of pea/oat intercrop. This finding is consistent with other researchers' evidence suggesting that the sequence of oat/pea intercrop harvested for forage followed by winter wheat will suppress warmseason weeds during the 2-year interval (Anderson, 2010).

\section{Conclusions}

The weed suppression effect of intercrops verses sole crops markedly differed during the plant growing period. Competitive abilities of crops were determined by plant productive density, height, mass, index of aggressiveness of cereals (Ac), and competition rate (CRc). More stable productive densities of intercrops were obtained in a loam soil (286-346 stems $\mathrm{m}^{-2}$ ) compared to a clay loam soil (211-275 stems $\left.\mathrm{m}^{-2}\right)$. Productive stem density of pea in crop structure was similar. According to plant height, spring cereals ranked as follows: oat > triticale $>$ wheat $>$ barley. Pea plants were the shortest and their height and mass tended to decline in intercrops. In intercrops, cereals had greater influence on weed suppression than pea.

During the crop growing season, sole cereals and pea/cereal intercrops provided better weed suppression than pea (semileafless pea cultivars). At Dotnuva, in denser crop densities, the total weed numbers during the maturity stage declined by $12.4-28.8$ weeds $\mathrm{m}^{-2}$ compared with that in spring;in pea crops, the reduction amounted to 3.1 weeds $\mathrm{m}^{-2}$. At Joniskelis, in the crops with a lower population density, the effect on weeds was lower. At lower crop population densities, weed suppression differences between sole crops and intercrops were inappreciable. At both experimental sites, the best weed suppression was exhibited by sole oat crop and its intercrop with pea; total weed numbers during the maturation stage declined by 24.4-28.8 weeds $\mathrm{m}^{-2}$ and 21.0-30.1 weeds $\mathrm{m}^{-2}$, respectively, compared with the spring period. At Dotnuva, all crops significantly reduced weed mass by 72.0-90.7\%, compared with pea crop. At Joniskelis, due to higher and uneven incidence of Cirsium arvense, the variation of weed mass was less consistent. According to increasing total weed mass, the crops ranked as follows: cereals < intercrops < pea. The lowest weed mass was identified in sole oat crop.

The variation of total weed numbers and mass was influenced by weed species. With low incidence of Viola arvensis, Veronica arvensis, Thlaspi arvense and more abundant counts of Galium aparine, all crops tended to reduce weed numbers compared with the spring period. With higher incidence of Viola arvensis, Veronica arvensis and Galium aparine (Joniskelis), their number (for Galium aparine also mass) decreased most in pea / oat and oat crops, compared with pea crop. With higher incidence of Fallopia convolvulus, its numbers were reduced only by pea/oat crop, while other crops increased its number compared with the spring period. However, Fallopia convolvulus, Viola arvensis, and Veronica arvensis mass significantly declined compared with that in pea crop. Sole cereal crops gave a better suppression of Stellaria media compared with intercrops. When the incidence of this weed was high, all crops significantly reduced its mass, compared with pea crop. In spring, when the incidence 
of Chenopodium album was very high (32.8-41.9 $\left.\mathrm{m}^{-2}\right)$ at the Dotnuva site, the number and mass of this weed significantly declined in intercrops and cereal crops compared with pea crop. When the incidence of this weed was lower $\left(4.2-8.5 \mathrm{~m}^{-2}\right)$, only its mass declined more markedly compared with pea crop. At both experimental sites, sole cereal crops, particularly especially oat, reduced weed mass more appreciably than intercrops. Crops had the lowest suppressive effect on perennial weeds, Sonchus arvensis and Cirsium arvense. In many crops, the number and mass of these weeds increased. Slightly less sensitive to crop suppression, especially to oat and pea / oat intercrop, was Sonchus arvensis. An increase in crop productive density had a significant negative effect on the number and/or mass of many weed species. For many climbing weed species, Galium aparine and Fallopia convolvulus, an increase in crop height significantly reduced their density. Short-growing weeds Veronica arvensis Stellaria media responded negatively to many competitive properties of crops.

The greatest negative effect on crop grain yield (2896.6-4270.4 kg ha-1) in a clay loam soil (Joniskelis) was exerted by weed numbers during crop maturation stage and its variation during the crop growing season. With a simultaneous increase in the number of these weeds (19.6-71.3 $\mathrm{m}^{-2}$ range), the yield of the crops tested statistically declined by $27.3 \mathrm{~kg} \mathrm{ha}^{-1}$. It was calculated that during the crop growing season, with one suppressed weed, grain yield increased by $18.8 \mathrm{~kg} \mathrm{ha}^{-1}$. In loamy soil (Dotnuva), the remaining number of weeds (27.0-54.7 weed $\mathrm{m}^{-2}$ ) during cereal maturity stage did not have any significant effect on crop yield (2555.4-3002.9 kg ha-1).

On a cultivated, heavy loam Cambisol, during the transition period from an intensive to an organic cropping system, the highest number of weeds emerged and persisted through the growing season in the third and fourth years of crop rotation. During the cereal maturity stage, sole cereal crops and their intercrops with peas had the greatest impact on weed numbers and mass, compared with their effect as pre-crops. Sole cereal crops and intercrops suppressed weeds during the growing season; therefore, in many crop rotations weed numbers and mass were significantly lower compared with a crop rotation with pea. Over a four-year period, during the maturity stage of cereals, in the crop rotations with intercrops, the total number of weeds was an average of $17.9 \mathrm{~m}^{-2}$ higher and $55.3 \mathrm{~m}^{-2}$ lower, and the total mass by $16.51 \mathrm{~g} \mathrm{~m}^{-2}$ higher and $63.31 \mathrm{~g} \mathrm{~m}^{-2}$ lower, compared with the respective crop rotations with sole cereal crops or pea. Averaged data showed, that during one year, significantly lower numbers of weeds were in the crop rotation with oat or its intercrop with pea.

\section{Acknowledgment}

The study has been supported by the Lithuanian Ministry of Agriculture and the Lithuanian Academy of Science.

\section{References}

Andersen, M. K.; Hauggaard-Nielsen, H.; Ambus, P. \& Jensen, E. S. (2005) Biomass production, symbiotic nitrogen fixation and inorganic $\mathrm{N}$ use in dual and tricomponent annual intercrops, Plant and Soil, Vol. 266, pp. 273-287, ISSN 0032-079X 
Andersen, M. K.; Hauggaard-Nielsen, H.; Weiner, J. \& Jensen, E. S. (2007) Competitive dynamics in two-component intercrops. Journal of Applied Ecology, Vol.44, No. 3, pp. 545-551, ISSN 0021-8901

Anderson, R.L.A. (2010) Rotation design to reduce weed density in organic farming. Renewable Agriculture and Food Systems, Vol. 25, No. 3, pp. 189-195, ISSN 1742-1705

Anil, L.; Park, R.; Phipps, R.H. \& Miller, F.A. (1998) Temperate intercropping of cereals for forage: a review of the potential for growth and utilization with particular reference to the UK. Grass and Forage Science, Vol. 53, pp. 301-317, ISSN 1365-2494

Auskalniene, O. \& Auskalnis, A. (2008) The influence of spring wheat plant density on weed suppression and grain yield. Zemdirbyste $=$ Agriculture, Vol. 95, No. 3, pp. 5-10, ISSN 1392-3196

Arlauskienė, A. \& Maikštėnienė S. (2008) Tarpinių pasėlių ir šiaudų naudojimo trąšai ịtaka trumpaamžių piktžolių plitimui vasariniuose miežiuose. Vagos, Nr. 79 (32), pp. 1323, ISSN 1648-116X

Banik, P; Midya, A.; Sarkar, B.K. \& Ghose, S.S. (2006) Wheat and chickpea intercropping systems in an additive series experiment: Advantages and weed smothering. Europea Journal of Agronomy, Vol. 24, Iss. 4, pp. 325-332, ISSN 1161-0301

Barbery, P. (2002) Weed management in organic agriculture: Are we addressing the right issues. Weed Research, Vol 42, pp. 177-193, ISSN 0043-1737

Berk, A.; Bramm, A.; Böhm, H.; Aulrich, K. \& Rühl, G. (2008) The nutritive value of lupins in sole cropping systems and mixed intercropping with spring cereals for grain production In: Proceedings of the 12th International Lupin Conference: Lupins for Health and Wealth, J.A. Palta and J.B. Berger (eds). 2008. '14-18 Sept. 2008, Fremantle, Western Australia. Canterbury, New Zealand. ISBN 0-86476-153-8

Berry, P.M.; Sylvester-Bradley, R.; Philipps, L.; Hatch, S.P.; Cuttle, F.W.; Gosling, P. (2002) Is the productivity of organic farms restricted by the supply of available nitrogen? Soil Use and Management, Vol. 18, pp. 248-255, ISSN 0266-0032

Bhadoria, P. B. S. (2011) Allelopathy: A Natural Way towards Weed Management. American Journal of Experimental Agriculture, Vol. 1, No. 1, pp. 7-20, ISSN 22310606

Bond, W. \& Grundy, A.C. (2001) Non-chemical weed management in organic farming systems. Weed Research, Vol. 41, No. 5, pp. 383-405, ISSN 0043-1737

Brisson, N. ; Bussiere, F. ; Ozier-Lafontaine, H. ; Tournebize, R. \& Sinoquet, H. (2004) Adaptation of the crop model STICS to intercropping. Theoretical basis and parameterisation. Agronomie, Vol. 24, pp. 1-9, ISSN 0249-5627

Bulson, H. A.; Snaydon, R. W. \& Stopes, C. E. (1997) Effects of plant density on intercropped wheat and field beans in an organic farming system. The Journal of Agricultural Science, Vol. 128, pp. 59-71, ISSN 0021-8596

Corre-Hellou, G.; Brisson, N.; Launay, M; Fustec, J. \& Crozat, I. (2007) Effect of root depth penetration on soil nitrogen competitive interactions and dry matter production in pea-barley intercrops given different soil nitrogen supplies. Field Crops Research, Vol. 103 (1), pp. 76-85, ISSN 0378-4290

Deveikyte I., Kadziuliene Z., Sarunaite L. (2009) Weed suppression ability of spring cereal crops and peas in pure and mixed stands. Agronomy Research, Vol. 7, No. 1, pp. 239244, ISSN 1406-894X 
Deveikyte, I.; Kadziuliene, Z.; Sarunaite, L. \& Feiziene, D. (2008) Investigations of weedsuppressing ability of leguminous plant under organic agriculture conditions. Vagos, Vol.79, No. 32, pp. 43-48, ISSN 1648-116X

Dibet, A.; Hauggaard-Nielsen, H.; Kasyanova, E.; Ruske, R.; Gooding, M.; Pristeri, A.; Monti, M.; Dahlmann, Ch.; Fragstein, P.; Ambus, P.; Jensen, E. \& Crozat, Y. (2006) Pea-barley intercropping for the control of weeds in European organic cropping systems. Poster at: Joint Organic Congress, Odense, Denmark, May 30-31, 2006.

Ghaley, B.B.; Hauggaard-Nielsen, H.; Høgh-Jensen, H. \& Jensen, E.S. (2005) Intercropping of wheat and pea as influenced by nitrogen fertilization. Nutrient Cycling in Agroecosystems, Vol. 73, No. 3, pp. 201-212, ISSN 1385-1314

Gharineh, M.H. \& Moradi-Telavat, M.R. (2009) Investigation of ecological relationship and density acceptance of canola in canola-field bean intercropping. Asian Journal of Agricultural Research, Nr. 3(1), pp.11-17, ISSN 18191894

Hauggaard-Nielsen, H.; Ambus, P. \& Jensen, E. S. (2001) Interspecific competition, N use and interference with weeds in pea-barley intercropping. Field Crops Research, Vol. 70, pp. 101 - 109, ISSN 0378-4290

Hauggaard-Nielsen, H.; Ambus, P. \& Jensen, E. S. (2003) The comparison of nitrogen use and leaching in sole cropped versus intercropped pea and barley. Nutrient Cycling in Agroecosystems, Vol. 65, pp. 289-300, ISSN 1385-1314

Hauggaard-Nielsen, H.; Jørnsgaard, B.; Kinane, J. \& Jensen, E. S. (2008). Grain legume cereal intercropping: The practical application of diversity, competition and facilitation in arable and organic cropping systems. Renewable Agriculture and Food Systems, Vol. 23, No. 1, pp. 3-12, ISSN 1742-1705

Hauggaard-Nielsen, H.; Knidsen, M. T.; Jørgensen, J. R. \& Jensen, E. S. (2006) Intercropping wheat with pea for improved wheat baking quality Intercropping of cereals and grain legumes for increased production, weed control, improved product quality and prevention of N-losses in European organic farming systems, Proceedings of the European Joint Organic Congress, pp. 268-269, ISBN 87-991343-3-0, Odense, Denmark, May 30-31, 2006

Hauggaard-Nielsen, H.; Mundus, S.; Jensen, E.S. (2009) Nitrogen dynamics following grain legumes and subsequent catch crop and the effects on succeeding cereal crops. Nutrient Cycling in Agroecosystems, Vol. 84, No. 3, pp. 281-291, ISSN 1573-0867

Jensen, E.S.; Ambus, N.; Bellostas, N.; Boisen, S.; Brisson, N.; Corre-Holou, G.; Crosat, Y. ; Dahlman, C. ; Dibet, A.; Fragstein, F.; Gooding, M. ; Hauggaard-Nielsen, H.; Kasyanova, E.; Launay, M. \& Pristeri, A. (2006) Intercropping of cereals and grain legumes for increased production, weed control, improved product quality and prevention of N-losses in European organic farming systems, Proceedings of the European Joint Organic Congress, pp. 180-181, ISBN 87-991343-3-0, Odense, Denmark, May 30-31, 2006

Koocheki, A.; Nassiri, M.; Alomoradi, L.; Ghorbani, R. (2009) Effect of cropping systems and crop rotations on weeds. Agronomy for Sustainable Development, Vol. 29, pp. 401-408, ISSN 1774-0746

Kristensen, L.; Olsen, J. \& Weiner, J. (2008) Crop density, sowing pattern, and nitrogen fertilization effects on weed suppression and yield in spring wheat. Weed Science, Vol. 56, No. 1, pp. 97-102, ISSN 0043-1745 
Lazauskas, P. (1990). Agrotechnika prieš piktžoles, Mokslas, ISBN 5-420-00206-X Vilnius, Lietuva

Lemerle, D.; Gill, G. S.; Murphy, C.E.; Walker, S R.; Cousens, R. D.; Mokhtari, S.; Peltzer, S. J.; Coleman, R. \& Luckett, D.J.(2001) Genetic improvement and agronomy for enhanced wheat competitiveness with weeds. Australian Journal Agricultural Research, Vol. 52, No. 5, pp. 527-548, ISSN 0004-9409

Liebman, M.; Davis, A. S. (2009). Managing weeds in organic farming systems: An Ecological Approach. Organic Farming: The Ecological System In: Francis, C. (Ed.) 173-195, American Society of Agronomy, ISBN 978-0-89118-173-6 Madison, Wisconsin, USA

Liebman, M. \& Davis, A.S. (2000) Integration of soil, crop and weed management in lowexternal-input farming systems. Weed Research, Vol. 40, No. 1, pp. 27-47, ISSN 00431737

Liebman, M. \& Dyck, E, (1993) Crop rotation and intercropping strategies for weed management. Ecological Applications, Vol. 3, No. 1, pp. 92-122 ISSN 1051-0761

Lithourgidis, A.S.; Vasilakoglou, I.B.; Dhima, K.V.; Dordas, C.A. \& Yiakoulaki, M.D. (2006) Forage yield and quality of common vetch mixtures with oat and triticale in two seeding ratios. Field Crops Research, Vol. 99, pp. 106-113, ISSN 0378-4290

Malézieux, E.; Crozat, Y; Dupraz, C.; Laurans, M.; Makowski, D.; Ozier-Lafontaine, H.; Rapidel, B.; de Tourdonnet, S. \& Valantin-Morison, M. (2009). Mixing plant species in cropping systems: concepts, tools and models. A review. Agronomy for Sustainable Development, Vol. 29, Nr.1, pp. 43-62, ISSN 1774-0746

Maiksteniene, S., Velykis, A., Arlauskiene, A. \& Satkus, A. (2006). Javų stelbiamosios galios prieš sunkiuose priemoliuose plintančias piktžoles tyrimai. Vagos, Vol. 72, No. 25, pp. 24-33, ISSN 1648-116X

Mariotti, M.; Masoni, A.; Ercoli, L. \& Arduini, I. (2006) Forage potential of winter cereahegume intercrops in organic farming. Italian Journal of Agronomy, Vol. 3, pp. 403-412, ISSN 1125-4718

Mohler, C. L. (2001) Enhancing the competitive ability of crops. In: Ecological Management of Agricultural Weeds, Matt Liebman, M.; Mohler, C. L.; Staver, C. P., pp. 1231-1269, Cambridge University Press, ISBN 978-052-1560-68-9, Cambridge, UK

Neumann, A.; Schmidke, K. \& Rauber, R. (2007). Effects of crop density and tillage system on grain yield and $\mathrm{N}$ uptake from soil and atmosphere of sole intercropped pea and oat. Field Crops Research, Vol., 100, No. 2-3, pp. 285-293, ISSN 0378-4290

Ofori, F. \& Stern, W.R. (1987) Cereal-legume intercropping system. Advances in Agronomy, Vol. 41, pp. 41-90, ISSN 0065-2113

Rasmussen, K. 2002. Influence of liquid manure application method on weed control in spring cereals. Weed Research, Vol., 42, No. 4, pp. 287-298, ISSN 0043-1737

Rauber, R.; Schmidtke, K. \& Kimpel-Freund, H. (2001). The performance of pea (Pisum sativum L.) and its role in determining yield advantages in mixed stands of pea and oat (Avena sativa L.). Journal of Agronomy and Crop Science, Vol. 187, No. 2, pp. 137144, ISSN 0931-2250

Protasov, N. (1995). The tendency of change of weed phytocenosis in the North-Eastern part of Byelorussia. In: Proceedings of the International conference: Weed Control in the Changing Situation of Farming in the Baltic Region, Lithuanian Academy of Agriculture, Trečiokas, K.; Liakas, V. (Eds.), pp. 203-210, Kaunas, Lithuania 
Špokienė, N. (1995) Vyraujančių trumpaamžių piktžolių dygimas dirvoje. In: Proceedings of the International conference: Weed Control in the Changing Situation of Farming in the Baltic Region, Lithuanian Academy of Agriculture, Trečiokas, K.; Liakas, V. (Eds.), pp. 267-275, Kaunas, Lithuania

Špokienè, N. \& Povilionienė E. (2003) Piktžolès. Lietuvos žemės ūkio universitetas, ISBN 9955-552-03-4, Kaunas, Lietuva

Singh, S.; Ladha J.K.; Gupta, R.K.; Bhushan L.; Rao, A.N.; Sivaprasad, B \& Singh, P.P. (2007) Evaluation of mulching, intercropping with Sesbania and herbicide use for weed management in dry-seeded rice (Oryza sativa L.). Crop Protection, Vol. 26, pp. 518524, ISSN 0261-2194

Subkowicz, P. \& Tendziagolska, E. (2005) Competition and productivityin mixture of oats and wheat. Journal of Agronomy and Crop Science, Vol. 191, No. 5, pp. 377-385, ISSN 0931-2250

Szumigalski, A. \& van Acker, R. (2005) Weed suppression and crop production in annual intercrops. Weed Science, Vol. 53, No. 6, pp. 813-825, ISSN 0043-1745

Thomson, D.J.; Stout, D.G. \& Moore, T. (1992) Forage production by four annual cropping sequences emphasizing barley irrigation in southern interior British Columbia. Canadian Journal of Plant Science, Vol. 72, pp. 181-15-85, ISSN 0008-4220

Urbatzka, P.; Gra $\beta$, R.; Haase, T.; Schüler, C. \& He $\beta$, J. (2009) Fate of legume-derived nitrogen in monocultures and mixtures with cereals. Agriculture, Ecosystems and Environment, Vol. 132, pp. 116-125, ISSN 0167-8809

Weigelt, A. \& Jolliffe, P. (2003) Indices of competition, Journal of Ecology, Vol. 91, pp. 707-720, ISSN 1365-2745

Willey, R.W. \& Rao, M.R. (1980) A competitive ratio for quantifying competition between intercrops. Experimental Agriculture, Vol. 16, pp. 117-125, ISSN 0014-4797 


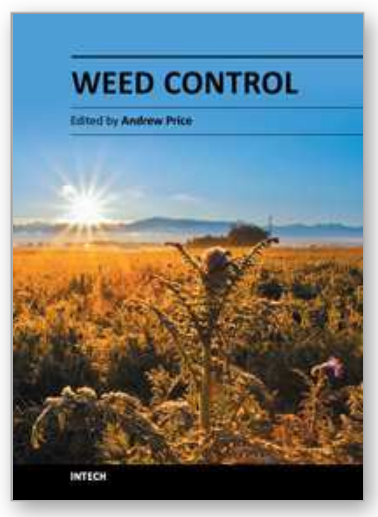

\author{
Weed Control \\ Edited by Dr. Andrew Price
}

ISBN 978-953-51-0159-8

Hard cover, 276 pages

Publisher InTech

Published online 29, February, 2012

Published in print edition February, 2012

Crop loss due to weeds has challenged agricultural managers since man began to develop the first farming systems. In the past century, however, much progress has been made to reduce weed interference in crop settings through effective yet mostly non-sustainable weed control strategies. With the commercial introduction of herbicides during the mid-1900's, advancements in chemical weed control tactics have provided efficient suppression of a broad range of weed species for most agricultural practices. Currently, with the necessity to design effective sustainable weed management systems, research has been pushing new frontiers on investigating integrated weed management options including chemical, mechanical as well as cultural practices. Author contributions to Weed Science present significant topics of research that examine a number of options that can be utilized to develop successful and sustainable weed management systems for many areas of crop production

\title{
How to reference
}

In order to correctly reference this scholarly work, feel free to copy and paste the following:

Lina Šarūnaitè, Aušra Arlauskienė, Irena Deveikytè Stanislava Maikštènienė and Žydrè Kadžiulienè (2012). Intercropping of Pea and Spring Cereals for Weed Control in an Organic Farming System, Weed Control, Dr. Andrew Price (Ed.), ISBN: 978-953-51-0159-8, InTech, Available from:

http://www.intechopen.com/books/weed-control/intercropping-of-pea-and-spring-cereals-for-weed-control-inan-organic-farming-system

\section{INTECH}

open science | open minds

\section{InTech Europe}

University Campus STeP Ri

Slavka Krautzeka 83/A

51000 Rijeka, Croatia

Phone: +385 (51) 770447

Fax: +385 (51) 686166

www.intechopen.com

\section{InTech China}

Unit 405, Office Block, Hotel Equatorial Shanghai

No.65, Yan An Road (West), Shanghai, 200040, China

中国上海市延安西路65号上海国际贵都大饭店办公楼 405 单元

Phone: +86-21-62489820

Fax: $+86-21-62489821$ 
(C) 2012 The Author(s). Licensee IntechOpen. This is an open access article distributed under the terms of the Creative Commons Attribution 3.0 License, which permits unrestricted use, distribution, and reproduction in any medium, provided the original work is properly cited. 